\title{
Acoustic Analysis of Obstruents in Some Igbo Dialects
}

\author{
Benita Nneka Anyasi \\ Department of Linguistics, Igbo and Other Nigerian Languages, University of Nigeria, Nsukka, Nigeria \\ Olusanmi Babarinde \\ Department of Linguistics, Igbo and Other Nigerian Languages, University of Nigeria, Nsukka, Nigeria \\ George Iloene \\ Department of Linguistics, Igbo and Other Nigerian Languages, University of Nigeria, Nsukka, Nigeria
}

\begin{abstract}
The study examines two dialects of the Igbo language, namely Aro and Mgbo, and analyses the acoustic structure of its obstruents as spoken by native speakers. This study sets out to, among other things, identify the obstruents which occur in the dialects, characterise these obstruents, analyse the acoustic properties, and find out the manner of relatedness of the obstruents in the two dialects. Four adult respondents (two for each dialect) aged between 60-80 years who are native speakers of the dialects were randomly selected. The data were recorded electronically using a high precision Sony ICD-UX560 recorder and transferred into the computer via Praat speech analyzer software. The data analysis was carried out with the SIL Speech Analyzer version 3.0.1 (1996-2007) and Praat. These were used in transcribing recorded tokens, cutting portions of tokens and analyzing the data. The measurement of the pitch, intensity and duration reveal some significant differences within the two dialects. In most Northern Igbo (Waawa) dialects, back rounded vowels are weakened as is evinced in [nyokə] and [yko]. Although the vowels are evident in the syllable structure, the final vowels are so weak that they are not phonetically interpretable.
\end{abstract}

Index Terms - acoustic properties, Igbo dialects, obstruents, Praat, SIL speech analyser

\section{INTRODUCTION}

Human language is undeniably the most systematized means of communication within a speech community. In spite of the fact that many languages spoken in Nigeria have been studied in depth, there are many dialects of these languages still awaiting careful acoustic study. Acoustics which is a branch of phonetics that deals with the physical properties of speech sounds, the nature of sound waves between mouth and ear. It examines such properties as attributes of its frequency, its period of production, fundamental frequency, mean squared amplitude of a waveform. Prinsloo (2000) notes that pitch is a crucial distinguishing feature to assess when examining the differences between pronunciation and accent in various groups of languages. He defines pitch as a voice feature which rises from the closure of the glottis and that the rate of occurrence is known as a person's voice pitch. Acoustic phonetics mainly has to do with what transpires from the moment a sound leaves the mouth, goes through any means to get to the recipient or hearer. It offers an opportunity to study the nature of speech signal for different sounds irrespective of the features that represent these sounds. Acoustic phonetics is instrumental science which relies on methods of saving, reproducing, visualising and analysing signals of speech. It is also a way to analyze and understand the nature of different sounds like vowels, semivowels, diphthongs, etc. Consonants are produced with total compression in the vocal tract, creating a section behind and another in front of the compression (cf. Jongman, 2010). The generic name for plosives, fricatives and affricates is obstruents.

Nissen (2003) notes that the acoustic realization of individual phonemes can vary considerably depending on multiple factors, some of which might be external to the production of the speech signal (cf. Nissen, 2003). One external source of variability may come from the ambient conditions of the speaking environment, such as room reverberation or background noise (Pisoni, 1997). Nissen (2003) posits that these types of external noise sources often alter acoustic components of the speech signal prior to it reaching the ears of the listener. Also, there is a considerable amount of acoustic variation between and within individual speakers. Between-speaker variation is due in large part to differing physical attributes of the speaker. Vocal tract size and shape, as well as vocal fold dimensions, are primary factors in determining the acoustic structure of a speech sound. Thus, the acoustic realization of speech sounds will differ according to the age, gender, and physical attributes of each individual speaker. He asserts that the acoustic parameters of the speech signal will change as a function of rate differences, changing voice quality, or context effects. In other words, a speaker will not always produce a particular phoneme exactly the same way. For example, the same acoustic cue can elicit differing phonetic percepts depending on the linguistic context (see Nissen, 2003). This phenomenon was illustrated in the classic study by Liberman and colleagues (1952). When a burst of acoustic energy 
centered around $1400 \mathrm{~Hz}$ was placed in front of a series of English vowels, listeners perceived different syllable types. If the burst preceded a high-front vowel, such as /i/, subjects identified the resulting syllable as /pi/. However, when the same burst was followed by a relatively lower vowel like $/ \mathrm{p} /$, the perceived syllable was consistent with $/ \mathrm{kp} /$. These early findings indicated that subjects perceived the same acoustic cue as different phonemes depending on the vowel context.

However, studies have discovered that different acoustic techniques produce the same phonemic percept when they are placed in different linguistic contexts. The word-initial sound /b/ in the words "beat", "bat", "bought", and "boot" is perceived by listeners/hearers as a /b/, even though the acoustic formant transitions for each perception of /b/ is relatively different subject to the succeeding vowel context (Sussman, Fruchter, Hilbert, \& Sirosh; 1998). This forms the hallmark of this study, to ascertain the behaviours of these obstruents in the environment of other speech sounds.

While Ikekeonwu (1986) in a linguistic and geographical classification of Igbo dialects identifies six dialect clusters, Nwaozuzu (2008) gives eight groups. The groups include the following:
i. West Niger Group of Dialects (WNGD)
iii. East-Central Group of Dialects (ECGD)
ii. East Niger Group of Dialects (ENGD)
v. South-Eastern Group of Dialects (SEGD)
iv. Cross River Group of Dialects (CRGD)
vii. South-Western Group of Dialects (SWGD)
vi. North-Eastern Group of Dialects (NEGD)
viii. Northern Group of Dialects (NGD)

Our focus in this study is North-Eastern Group of Dialects (NEGD) which comprises the dialects of Izhi, Ikwo, Ezaa, and Mgbo and Aro with varieties spoken in Arochukwu and other Arọ settlements in Ebonyi state. Arochukwu is sometimes referred to as Arochuku or Aro-Okigbo, (pronounced Aruchukwu). It is composed of 19 villages with an overall leader called Eze Aro.

\section{CONCEPTUAL REVIEW}

\section{A. Acoustic Experimentation}

It can also be defined as the study of the acoustic characteristics of speech which is consisted in the variations of air constriction that emanates from physical interruptions of air particles that are produced as a result of the egresive air flow from the lungs. This flow of air makes the air particles to swing back and forth (cluster together and separate), thereby bringing about decreases and increases in the pressure of the air. As a result of these movements, there is pressure from the speaker to the listener. Amplitude, frequency, pitch, cycle, unit, period are some properties that portray sound waves. Amplitude is the size of vibrations; larger vibrations give rise to greater amplitude which also increases loudness. The quantity of cycles in one second is frequency and it is expressed in hertz (Hz). When frequency increases, there is a resultant increase in pitch. The time for the completion of one cycle is known as a period. Pitch is the extent to which a sound is high or low and it depends on the rate of vibration of the vocal cords. A cycle is a sequence of one increase and one decrease in air pressure. The speed at which the vocal cords vibrate can be measured in terms of the number of times they complete cycles of opening and closing per hundredth milliseconds. The unit is called the fundamental frequency (Fo). It is also the rate at which the speech pressure waveforms repeat.

The use of instruments in acoustic investigations has been viewed as an indispensable aspect that the process is also referred to as instrumental phonetics. Acoustic experimentation is therefore a system of investigation which involves the use of acoustic instruments in describing and analyzing language data. Donwa-Ifode (1995) discusses the advantages of incorporating instrumental investigation in the analysis of prosodic language data. The use of instruments is very crucial to acoustic phonetics because linguistics has to be as objective and scientific as possible. Illustratively according to her, we first make observations through our senses of hearing, sight and touch; then we make hypothesis which the instruments confirm, negate or modify. Thus, the instrumental work serves as a check on the excesses of subjectivity by our observations. Furthermore, instrumental work adds detail to our observations. She however observes that instruments have their limitations because it is easy to abuse the use of instruments. For this reason, their use is secondary and not primary as they are means to an end and not an end in themselves.

\section{B. Instrumental Phonetics}

Acoustic phonetics deals with the acoustic features of speech sounds. This includes an examination and description of speech sounds in respect to its physical features, like frequency, intensity, and duration. Descriptions of speech sounds using these criteria date back to 1830, however, the invention of spectrograph for sound description was in 1945 and this feat was a significant technological breakthrough; it made the analysis and visualization of the speech signal possible. Rousselot is generally regarded as the father of experimental phonetics. Rousselot used the kymograph in the acoustic study of speech sound.

\section{THEORETICAL STUDIES}

\section{A. Classical Phonology}

Classical phonology or phonemics, according to Ogunsiji and Sunday (2011), is an aspect of structural grammar. It focuses on the study of the structures of language. The foregoing emphasises the distinction between 'form' and 'substance'. In other words, the main preoccupation of classical phonology, according to Sommerstein (1977), is the 
examination of the phonic features functioning in the particular language under investigation to clearly differentiate between utterances.

\section{B. Distinctive Feature Theory}

Distinctive features are the phonetic properties of phonemes that account for their ability to bring about difference in the meanings of words, e.g. voice, tense, etc. Mannell (2008) avers that distinctive feature theory, based on Roman Jakobson's work and the work of Trubetzkoy, was first formalised by Roman Jakobson in 1941 and remains one of the most significant contributions to phonology. He states that, Jakobson's original formulation of distinctive feature theory was based on these ideas:-

1. All features are privative (i.e. binary). This means that a phoneme either has the feature e.g. [+voice] or it does not have the feature. e.g. [-voice].

2. There is a difference between phonetic and phonological features

i. Distinctive Features are phonological features.

ii. Phonetic features are surface realisations of underlying Phonological features.

iii. A phonological feature may be realised by more than one phonetic feature, e.g. [flat] is realised by labialisation, velarisation and pharyngealisation.

3. A small set of features is able to differentiate between the phonemes of any single language.

4. Distinctive features may be defined in terms of articulatory or acoustic features, but Jakobson's features are primarily based on acoustic descriptions.

Umeodinka (2016) notes that the theory provides sufficient information which can be used to completely specify all phonemes, each sound in the array or matrix appears as a unique bundle of features and distinctive features offer some assistance in explaining the structure of sound systems. Hall (2007) also argues that without the classes of sounds defined by distinctive feature values, the phonological rules and processes would not have been possible.

\section{Generative Phonology}

Generative phonology is a theory of phonology within the framework of generative grammar by Chomsky and Halle's (1968) 'The Sound Pattern of English (SPE)'. This theory presents underlying representation that allows phonological rules and principles to be more transparently and economically stated. Mbah (2016:33) asserts that generative phonology concerns itself with principles that guide the pronunciation of words, segments, phrases and even sentences and how they are derived from more general principles, which are operative in all languages. He further lists the premises of generative school of phonology as follows:

a. Phonological structure portrays the linguistic competence of the individual native speaker to work out a phonetic representation for the possible infinite number of sentences which can be generated through the syntactic component of the grammar of the language; and

b. This competence can be scientifically investigated.

Mbah and Mbah (2010:171) state that the proponents of this theory claim that linguistic description should aim at constructing a grammar that is capable of generating linguistic forms. They further maintain that such a grammar should be able to contain phonological rules which apply to the underlying forms of the language and yield surface phonetic representations. Thus, the rules are much more than a mere inventory of phonemes and allophones. The major weakness of generative phonology lies in its linearity condition where sound segments are sequentially treated, one after the other. As a result of the linearity principle, suprasegmentals, which cannot be divorced from the segmental in utterances, are not accounted for in generative phonology.

\section{Acoustic Theory of Speech Production}

The acoustic theory of speech production or the source filter theory was developed by Fant in (1960). It is called source filter theory because it is based on a linear mathematical model. The theory tends to explore proper articulatoryacoustic relationships; however, it also provides a foundation for many procedures for the acoustic analysis of speech. It gives a practical introduction to how sound is created by a source and modified by a filter in the vocal tract, and other biological and non-biological systems. The theory also introduces the human vocal apparatus, and some ways to represent the acoustic properties of speech. The theory pays attention to articulation of speech sound and considers how the mobility of the tongue, jaw, lips, soft palate and pharyngeal walls allow the production of a wide range of sounds, each at several places of articulation within the vocal tract.

This theory is also not suitable for this work because it is a theory that is based on a linear mathematical model which pays attention to articulation of speech sounds and considers how the mobility of the tongue, jaw, lips, soft palate and pharyngeal walls allow the production of a wide range of sounds, each at several places of articulation within the vocal tract.

\section{E. Empirical Studies}

Schmid, Lee, \& Zee (2011) carried out an acoustic analysis of palatal obstruents in two Romance varieties and they opined that palatal stops and affricates are relatively uncommon in the languages of the world unlike velar stops and post-alveolar affricates. They discovered that in some languages, palatal stops undergo a diachronic or historical shift 
and combines with post-alveolar affricates. The study used a spectral analysis of palatal stops in two Romance dialects. The results showed that the acoustic difference between post-alveolar and palatal obstruents is rather scanty in Vallader than in Sangiovannese, where in turn inter-speaker differences are more sizeable. The research gave spectral analysis of six types of consonants in two Romance dialects and this has proved that the Center of Gravity constitutes a valuable idea to place of articulation, allowing to differentiate between post-alveolar and palatal obstruents in particular.

An acoustic analysis of voiceless obstruents produced by adults and typically developing children was carried out by Nissen in 2003. He asserts that although researchers have made efforts toward knowing the mechanism of speech in terms of its production and perception, the complex interrelationships between the acoustic structures of speech sounds and the resulting psychological percepts are yet to be fully and explicitly explained. More particularly, there is an insufficient knowledge of the acoustic nature of speech produced by younger children. So, the study looked at the acoustic structure of voiceless obstruents of adults and typically developing children from 3 to 6 years of age. Forty speakers from four different age brackets rendered word-initial voiceless obstruents /p, t, k, f, $\Theta$, s, J/ in real word CV contexts, likewise a similar series of intervocalic obstruents taken from non- existing words (VCV phonetic context). The acoustic nature of the speech tokens was explained in terms of multiple acoustic parameters (durations, normalized amplitude, spectral peak location, spectral slope, and spectral moments). The findings of the research showed that multiple acoustic parameters of voiceless stops and fricatives vary systematically in the function of place of articulation, vowel context, speaker age, and gender. Specifically, it was discovered that the spectral peak location, slope, and the first three spectral moments were able to distinguish between differing places of articulation. Furthermore, gender differences for several acoustic properties are seen in children at a relatively young age while the acquired sibilant contrast between $/ \mathrm{s} /$ and $/ \mathrm{J} /$ are discovered to be less differentiated in children than in adults.

Obianika (2012) studies the interface of tone and morpheme in Abankaleke Igbo. Her work sets out to, among other things, identify the contrastive tone levels in Izii and Ezaa varieties of Igbo, find out the extent to which the differences perceptible in tone within Izii and Ezaa contribute to the observable variations among the dialects and with the Standard Igbo, determine the relationship between the syllable structures of Izii, Ezaa and the Standard Igbo and to verify if the differences observable in the Abakaleke dialects and the Standard Igbo are significant enough to classify them as a separate linguistic system. Random sampling technique was used and three adult speakers of Izii, Ezaa and the Standard Igbo were sampled respectively. A suitable version of the 400 items contained in Ibadan wordlist was used and the collected data were electronically recorded. The data analysis was carried out with the Speech Tools Analyzer Version 3, 0.1 (1999-2007) and Phonology Assistant Version 2.2 (1995-2005) software packages developed by the Summer Institute of Linguistics (SIL) International. The results of the phonological and acoustic analyses showed that the differences between the Abankaleke dialects and the Standard Igbo were not significant enough to classify them as a separate linguistic system.

\section{Methodology}

Simple random sampling technique was adopted in selecting four adult respondents who are native speakers aged between 60 and 80 years (two for each dialects) for data gathering. The respondents produced each token trice and the researcher chose the best produced token for accurate analysis. The data collected in a high precision cassette recorder via interview were digitalized by transferring them into the computer using the Praat speech analyzer software. The respondents were presented with an adapted form of Ibadan wordlist of 400 Basic Items (Trial) English version as presented in Udoh (2003) (a total of 242 items which the writer feels could contain obstruents when translated to these dialects were selected from the list). These recordings were transcribed in the orthographic and phonetic representations. The data analysis was carried out with the SIL Speech Analyzer version 3.0.1 (1996-2007), Sound Forge and Praat. These were used in segmenting the recorded tokens, cutting portions of tokens and noting the acoustic properties of recorded words. The advantage of the packages is that they are efficient in segmenting and in carrying out other acoustic analyses such as measuring fundamental frequency, spectrographic and spectral analyses and duration measurements of speech sounds. Praat speech analysis software was used to digitalize the data for acoustic phonetic analysis. The mean average pitch levels, intensity and duration of the selected tokens were summed up. Descriptive method of data analysis was used in reporting our observation of data in this work. According to Ladefoged and Maddieson (1996:1), segmental description of a language is the most suitable way of communicating the results of phonetic analysis to a wide range of readers.

\section{DATA PRESENTATION AND ANALYSIS}

\section{A. The Consonantal Sounds of Aro and Mgbo Dialects}

\section{Aro consonant phoneme inventory}

Arọ consonants are articulated through seven manners namely; three obstruent classes (plosives, fricatives and affricates) and four sonorant classes (nasal, approximant, lateral, roll). There are 28 consonant phonemes in 9 places and 7 manners of articulation. Arọ dialect, unlike Mgbo dialect, does not articulate any phoneme as a labialized alveolar. 
TABLE 1

ARọ CONSONANT CHART

\begin{tabular}{|c|c|c|c|c|c|c|c|c|c|c|}
\hline & Bilabial & $\begin{array}{l}\text { Labio- } \\
\text { dental }\end{array}$ & Alveolar & $\begin{array}{l}\text { Labialis } \\
\text { ed } \\
\text { alveolar }\end{array}$ & $\begin{array}{l}\text { Post } \\
\text { alveolar }\end{array}$ & Palatal & Velar & $\begin{array}{l}\text { Labialised } \\
\text { velar }\end{array}$ & $\begin{array}{l}\text { Labio- } \\
\text { velar }\end{array}$ & Glottal \\
\hline Plosives & $\mathrm{b}$ & & $\mathrm{d}$ & & & & $\mathrm{k}$ & kw gw & $\widehat{\mathrm{kp}} \mathrm{gb}$ & \\
\hline Nasals & $\mathrm{m}$ & & $\mathrm{n}$ & & & $\mathrm{n}$ & $\mathrm{D}$ & nw & & \\
\hline Fricatives & & f $\quad$ V & $\mathrm{z}$ & & $\int 3$ & & & & & $\mathrm{~h}$ \\
\hline Affricates & & & & & $\mathrm{t} \int \mathrm{d} 3$ & & & & & \\
\hline Laterals & & & 1 & & & & & & & \\
\hline Approximants & & & & & & & $\mathrm{j}$ & & $\mathrm{W}$ & \\
\hline Rolls & & & $\mathrm{r}$ & & & & & & & \\
\hline
\end{tabular}

Arọ consonant sounds inventory

\begin{tabular}{|c|c|c|c|}
\hline$/ \mathrm{p} / \mathrm{as}$ in & àpàtà & /àpàtà/ & 'thigh' \\
\hline$/ \mathrm{b} / \mathrm{as}$ in & òbàrà & /òbàrà/ & 'blood' \\
\hline$/ t /$ as in & ụttọ́ & /ùtó/ & 'sweet' \\
\hline$/ d /$ as in & ḿmádí & /ḿmádı/ & 'person' \\
\hline$/ \mathrm{k} /$ as in & íké & /íké/ & 'hard' \\
\hline /g/ as in & ágígá & /ágigá/ & 'needle' \\
\hline$/ \mathrm{kw} /$ as in & úkwúù & /úkwúù/ & ‘big' \\
\hline /gw/ as in & òbògwụ̀ & /òbògwơ/ & 'duck' \\
\hline$/ \mathrm{kp} /$ as in & ákpú & /ákpós/ & 'cassava' \\
\hline /gb/ as in & gbứpù̀ & /gbúpò/ & 'spit' \\
\hline$/ \mathrm{m} /$ as in & ńkúmè & /ńkúmè/ & 'stone' \\
\hline$/ \mathrm{n} /$ as in & ọ́nụ́ & /ónơ/ & 'mouth' \\
\hline$/ \mathrm{n} /$ as in & únyìrì & /únìrì/ & 'charcoal' \\
\hline$/ \mathrm{y} /$ as in & ńkúmè & /ńkúmè/ & 'stone' \\
\hline /nw/as in & nwúnyè & /nwúnè/ & 'wife' \\
\hline /f/ as in & gáfé & /gáfé/ & 'pass' \\
\hline$/ \mathrm{v} /$ as in & óvó & /óvó/ & 'soup’ \\
\hline$/ \mathrm{s} /$ as in & ósè & /ósè/ & 'pepper' \\
\hline$/ z /$ as in & ázì & /ázI/ & 'fish' \\
\hline$/ \mathrm{J} / \mathrm{as}$ in & ǹshí & $/ \mathrm{n} \int \mathrm{I} /$ & 'faeces' \\
\hline$/ 3 /$ as in & ògàzị & /ògàzi/ & 'guinea fowl' \\
\hline$/ \mathrm{h} /$ as in & ụhá & /òhá/ & 'lie’ \\
\hline$/ \mathrm{t} f /$ as in & ộkọ́chì & /ókót $\int \mathrm{I} /$ & 'dry season' \\
\hline$/ d z /$ as in & éjù & /édzù/ & 'snail' \\
\hline$/ 1 /$ as in & úwèlè & /úwèlè/ & 'hoe' \\
\hline$/ \mathrm{j} /$ as in & íyí & /íyí/ & 'river' \\
\hline$/ \mathrm{w} /$ as in & áwò & /áwว̀/ & 'toad' \\
\hline$/ \mathrm{r} /$ as in & úrá & /órá/ & 'sleep' \\
\hline
\end{tabular}

\section{Mgbo consonant phoneme inventory}

Mgbo consonants are equally articulated through seven manners namely; three obstruent classes (plosives, fricatives and affricates) and four sonorant classes (nasal, approximant, lateral, roll). There are 37 consonant phonemes in 10 places and 7 manners of articulation.

TABLE 2

MGBo CONSONANT CHART

\begin{tabular}{|c|c|c|c|c|c|c|c|c|c|c|}
\hline & Bilabial & $\begin{array}{l}\text { Labio- } \\
\text { dental }\end{array}$ & Alveolar & $\begin{array}{l}\text { Labialised } \\
\text { alveolar }\end{array}$ & $\begin{array}{l}\text { Post- } \\
\text { alveolar }\end{array}$ & Palatal & Velar & $\begin{array}{l}\text { Labialised } \\
\text { velar }\end{array}$ & $\begin{array}{l}\text { Labio- } \\
\text { velar }\end{array}$ & Glottal \\
\hline Plosives & $\mathrm{p} \quad \mathrm{b}$ & & $\mathrm{t} \quad \mathrm{d}$ & & & c $\quad \mathrm{J}$ & $\mathrm{k} \quad \mathrm{g}$ & kw $\quad$ gw & $\widehat{\mathrm{kp}} \mathrm{gb}$ & \\
\hline Nasals & $\mathrm{m}$ & & $\mathrm{n}$ & & & $\mathrm{n}$ & $\eta$ & jw & & \\
\hline Fricatives & $\phi \quad \beta$ & $\begin{array}{ll}f & v\end{array}$ & S $\quad$ Z & & $\int 3$ & & & & & $\mathrm{~h}$ \\
\hline Affricates & $\mathrm{pf}$ bv & & ts $\mathrm{dz}$ & & $\mathrm{t} \int \mathrm{d} 3$ & & & & & \\
\hline Laterals & & & 1 & $1^{w}$ & & & & & & \\
\hline $\begin{array}{l}\text { Approxim } \\
\text { ants }\end{array}$ & & & & & & $\mathrm{j}$ & & & w & \\
\hline Rolls & & & $\mathrm{r}$ & & & & & & & \\
\hline
\end{tabular}

Mgbo consonant sounds inventory

$\begin{array}{llll}/ \mathrm{p} / \text { as in } & \text { ùpì } & \text { /òpI/ } & \text { 'horn' } \\ / \mathrm{b} / \text { as in } & \text { èbà } & \text { /c̀bà/ } & \text { 'fat' } \\ / \mathrm{t} / \text { as in } & \text { étó } & \text { /ćtó/ } & \text { 'three' } \\ \text { /d/ as in } & \text { ógódó } & \text { /ógódó/ } & \text { 'cassava' }\end{array}$




\begin{tabular}{|c|c|c|c|}
\hline /c/ as in & ụ́tchá & /úcá/ & 'white' \\
\hline$/ \mathrm{f} /$ as in & ídjè & /ífè/ & ‘walk’ \\
\hline$/ \mathrm{k} /$ as in & kụá & /kùál & 'beat' \\
\hline$/ g /$ as in & ụ́gá & /ưgá/ & 'chin' \\
\hline$/ \mathrm{kw} /$ as in & kwé & /kwé/ & 'weave' \\
\hline$/ g w /$ as in & ígwè & /ígwè/ & ‘iron' (metal) \\
\hline$/ \mathrm{kp} /$ as in & ọ́kpụ & 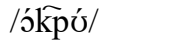 & 'bone' \\
\hline$/ \mathrm{gb} / \mathrm{as}$ in & àgbò & /àgbò/ & 'plantain' \\
\hline$/ \phi /$ as in & ợfụu & /ófưó/ & 'new' \\
\hline$/ \beta /$ as in & ábhá & láßá/ & 'year' \\
\hline /f/ as in & nfứtụ́ & /yfứtơ/ & 'arm' \\
\hline$/ v /$ as in & ọvụ́ & /óvú/ & 'thorn' \\
\hline /s/ as in & èsáá & lèsáá/ & 'seven' \\
\hline$/ z /$ as in & ụ́zò & /úż̀/ & 'road' \\
\hline$/ \int /$ as in & égbíshì & /ćgbishi/ & 'hair' \\
\hline$/ 3 /$ as in & ògàzì & /ògàzı/ & 'guinea fowl' \\
\hline$/ \mathrm{h} /$ as in & hứmá & /hưmá/ & 'see' \\
\hline$/ \mathrm{m} /$ as in & nụ́má & /nứmá/ & 'hear' \\
\hline$/ \mathrm{n} /$ as in & ógólónú & /ógólónú/ & 'groundnut' \\
\hline$/ \mathrm{n} /$ as in & mámínyí & /mámını/ & 'urine' \\
\hline$/ \mathrm{y} /$ as in & ńkụ́tá & /ykưtá/ & 'dog' \\
\hline$/ \mathrm{nw} /$ as in & ínwứ nwá & /Inwứ nwá/ & 'give birth' \\
\hline$/ \mathrm{pf} /$ as in & ḿpfụ́ & /mpfó/ & 'palm' \\
\hline /bv/ as in & ébvù & /ébvù/ & 'song' \\
\hline /ts/ as in & útsú & /útsú/ & 'penis' \\
\hline$/ \mathrm{dz} /$ as in & ọdzụ̀ & /ódzò/ & 'tail' \\
\hline$/ \mathrm{t} f /$ as in & ọ́kọ́chì & /ókót $\int \mathrm{I} /$ & 'dry season' \\
\hline$/ \mathrm{d} z /$ as in & jákí & /dzáki/ & 'donkey' \\
\hline$/ 1 /$ as in & álímú & /álımú/ & 'orange' \\
\hline$/ \mathrm{l}^{\mathrm{w}} / \mathrm{as}$ in & lụ́é & / lwúé/ & 'swallow' \\
\hline$/ \mathrm{j} /$ as in & ágứíyí & /ágứíyí/ & 'crocodile' \\
\hline$/ \mathrm{r} /$ as in & ìrí & /îrí/ & 'ten' \\
\hline$/ \mathrm{w} /$ as in & ówú & /ówú/ & 'thread' \\
\hline
\end{tabular}

B. Characteristics of Obstruents in Aro and Mgbo Dialects

TABLE 4

OBSTRUENTS IN ARọ AND MGBo DIALECTS

\begin{tabular}{|c|c|c|c|c|c|}
\hline Phoneme & Characteristics & Arọ & Mgbo & Standard Igbo & English gloss \\
\hline \multirow[t]{2}{*}{$/ \mathrm{p} /$} & $\begin{array}{l}\text { Voiceless bilabial } \\
\text { plosive }\end{array}$ & ['́pitI] & [ÉpitI] & [ápıtI] & Mud \\
\hline & & [mpì] & [ن̀pI] & [mpì] & Horn \\
\hline \multirow[t]{2}{*}{$/ \mathrm{b} /$} & $\begin{array}{l}\text { Voiced } \\
\text { plosive }\end{array}$ & [ḿbè] & [mbéfú] & [ḿbè] & Tortoise \\
\hline & & [bıā] & {$\left[\mathrm{b}^{\mathrm{j}} \mathrm{Ia}\right]$} & [biā] & Come \\
\hline \multirow[t]{3}{*}{$/ \mathrm{t} /$} & $\begin{array}{l}\text { Voiceless alveolar } \\
\text { plosive }\end{array}$ & [àpàtà] & [ưtákú] & [àpàtà] & Thigh \\
\hline & & [úté] & [úté] & [úté] & Mat \\
\hline & & [ntóhé] & [tòjá] & [tòghéé] & Untie \\
\hline \multirow[t]{3}{*}{$/ \mathrm{d} /$} & $\begin{array}{ll}\text { Voiced alveolar } \\
\text { plosive }\end{array}$ & [ádá] & [ćdá] & [dàà] & Fall \\
\hline & & [d’̀kāa] & [dòkāa] & [d’̀kāa] & Tear \\
\hline & & [mmádi] & [úmádò] & [mmádò] & Person \\
\hline \multirow[t]{3}{*}{$/ \mathrm{k} /$} & $\begin{array}{ll}\text { Voiceless } & \text { velar } \\
\text { plosive } & \\
\end{array}$ & [nfikó] & [ykò] & [nfikó] & Crab \\
\hline & & [1́kèwà] & [kéyé] & [kèwáá] & Split \\
\hline & & [tfikòlátá] & [tfikòbé] & [kpókótá] & Gather \\
\hline$/ g /$ & $\begin{array}{ll}\text { Voiced } & \text { velar } \\
\text { plosive } & \end{array}$ & [góónwó] & [gú] & [gí] & You \\
\hline$/ \mathrm{kw} /$ & $\begin{array}{l}\text { Voiceless labialized } \\
\text { velar plosive }\end{array}$ & [Ikwá ćkwò] & [Ikwé úkpó] & [Ikwá ákwá] & Sew \\
\hline \multirow[t]{4}{*}{$/ \widehat{\mathrm{kp}} /$} & $\begin{array}{l}\text { Voiceless } \\
\text { labiovelar plosive }\end{array}$ & 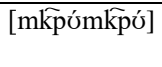 & [mk̂írìjî] & 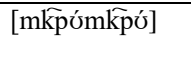 & Short \\
\hline & & [ákpớर̄pó] & [ákpéhớ] & [ákpókpós] & Skin \\
\hline & & [òk̂́ú] & [òkpú] & [òkpú] & Hat \\
\hline & & [àkpà] & [غ̇kpà] & [àkpà] & Bag \\
\hline
\end{tabular}




\begin{tabular}{|c|c|c|c|c|c|}
\hline /gb/ & $\begin{array}{l}\text { Voiced labiovelar } \\
\text { plosive }\end{array}$ & [gbópò] & [gbúfù] & [gbúpò] & Spit out \\
\hline /gw/ & $\begin{array}{l}\text { Voiced labialized } \\
\text { velar plosive }\end{array}$ & [ígwè] & [ígwè] & [ígwè] & Iron \\
\hline /s/ & $\begin{array}{l}\text { Voiceless alveolar } \\
\text { fricative }\end{array}$ & [ósò] & [ósè] & [ósè] & Pepper \\
\hline $\mid \mathrm{z} /$ & $\begin{array}{l}\text { Voiced alveolar } \\
\text { fricative }\end{array}$ & [ázI] & [ázò] & [ázò] & Fish \\
\hline $\mid \int /$ & $\begin{array}{l}\text { Voiceless post- } \\
\text { alveolar fricative }\end{array}$ & {$\left[\mathrm{n} \int \mathrm{I}\right]$} & {$\left[\mathrm{n} \int \mathrm{I}\right]$} & {$\left[\mathrm{n} \int \mathrm{I}\right]$} & Faeces \\
\hline $13 /$ & $\begin{array}{l}\text { Voiced post- } \\
\text { alveolar fricative }\end{array}$ & [’̀gàzı] & [’̀gàzı] & [’̀̀gàzI] & Guinea fowl \\
\hline \multirow[t]{3}{*}{$/ \mathrm{d} z /$} & $\begin{array}{l}\text { Voiced post- } \\
\text { alveolar affricate }\end{array}$ & [dí] & [dzí] & [dí] & Husband \\
\hline & & [ndzó] & [ndzó] & [ndzó] & Bad \\
\hline & & [díbrá] & [dzíbıá] & [díbrá omenala] & Doctor (native) \\
\hline \multirow[t]{2}{*}{$/ \mathrm{t} \int /$} & $\begin{array}{l}\text { Voiceless post- } \\
\text { alveolar affricate }\end{array}$ & [mét]ié] & [gòtfié] & [métfié] & Close (door) \\
\hline & & [t fikólátá] & [t fikj̀bć] & [t fikólátá] & Gather \\
\hline \multirow[t]{2}{*}{$/ \mathrm{ts} /$} & $\begin{array}{l}\text { Voiceless alveolar } \\
\text { affricate }\end{array}$ & [ờ'́́] & [ùtsó] & [òtó] & Sweet \\
\hline & & [úsú] & [úbátsú] & [úsú] & Bat \\
\hline$/ \phi /$ & $\begin{array}{l}\text { Voiceless bilabial } \\
\text { fricative }\end{array}$ & [óvớró] & [ófướ] & [óhớró] & New \\
\hline $\mid \mathrm{J} /$ & $\begin{array}{ll}\text { Voiced palatal } \\
\text { plosive }\end{array}$ & [ídzè] & [ífè] & [ídzè] & Walk \\
\hline$/ \mathrm{y} /$ & $\begin{array}{ll}\text { Voiced } & \text { velar } \\
\text { fricative } & \end{array}$ & [òwú] & [òwú] & [òwú] & Thread \\
\hline$/ \beta /$ & $\begin{array}{l}\text { Voiced bilabial } \\
\text { fricative }\end{array}$ & [ávò] & [áßá] & [áfò] & Year \\
\hline$/ \mathrm{pf} /$ & $\begin{array}{l}\text { Voiceless bilabial } \\
\text { affricate }\end{array}$ & [ókwú] & [ópfú] & [ḿkpúrúókwú] & Word \\
\hline$/ \mathrm{dz} /$ & $\begin{array}{ll}\text { Voiced } & \text { alveolar } \\
\text { affricate } & \\
\end{array}$ & [mmádi] & [úmádò] & [mmádò] & Person \\
\hline$/ \mathrm{c} /$ & $\begin{array}{l}\text { Voiceless palatal } \\
\text { plosive }\end{array}$ & [ứtfá] & [ưcá] & [ứtfá] & White \\
\hline /f/ & $\begin{array}{l}\text { Voiceless labio- } \\
\text { dental fricative }\end{array}$ & [ókwòrò] & [ófùrù] & [ókwòrò] & Okra \\
\hline$/ \mathrm{v} /$ & $\begin{array}{l}\text { Voiced labio-dental } \\
\text { fricative }\end{array}$ & [ḿbó] & [ḿvó] & [ḿ่vó] & Nails (finger) \\
\hline$/ \mathrm{bv} /$ & $\begin{array}{ll}\text { Voiced } & \text { bilabial } \\
\text { affricate } & \end{array}$ & [égwú] & [ébvú] & [égwú] & Song \\
\hline
\end{tabular}

\section{Distinctive Phoneme Features of Obstruents across the Two Dialects}

TABLE 5

OBSTRUENTS AND THEIR DisTinctive FEATURES

\begin{tabular}{|l|l|l|l|l|l|l|l|l|l|l|l|l|l|l|l|l|l|l|l|l|l|l|l|l|l|l|}
\hline & $\mathrm{p}$ & $\mathrm{b}$ & $\mathrm{t}$ & $\mathrm{d}$ & $\mathrm{c}$ & $\mathrm{J}$ & $\mathrm{k}$ & $\mathrm{g}$ & $\begin{array}{l}\mathrm{k} \\
\mathrm{p}\end{array}$ & $\begin{array}{l}\mathrm{g} \\
\mathrm{b}\end{array}$ & $\begin{array}{l}\mathrm{k} \\
\mathrm{w}\end{array}$ & $\begin{array}{l}\mathrm{g} \\
\mathrm{W}\end{array}$ & $\mathrm{g}$ & $\mathrm{B}$ & $\mathrm{f}$ & $\mathrm{v}$ & $\mathrm{s}$ & $\mathrm{z}$ & $\mathrm{J}$ & $\mathrm{J}$ & $\mathrm{f}$ & $\mathrm{p}$ & $\mathrm{b}$ & $\mathrm{t}$ & $\mathrm{t}$ & $\mathrm{d}$ \\
$\mathrm{f}$ & $\mathrm{v}$ & $\mathrm{J}$ & $\mathrm{3}$ \\
\hline Bilabial & + & + & - & - & - & - & - & - & - & - & - & - & + & + & - & - & - & - & - & - & - & + & + & - & - & - \\
\hline $\begin{array}{l}\text { Labio- } \\
\text { dental }\end{array}$ & - & - & - & - & - & - & - & - & - & - & - & - & - & - & + & + & - & - & - & - & - & - & - & - & - & - \\
\hline Alveolar & - & - & + & + & - & - & - & - & - & - & - & - & - & - & - & - & + & + & - & - & - & - & - & + & - & - \\
\hline $\begin{array}{l}\text { Post- } \\
\text { alveolar }\end{array}$ & - & - & - & - & - & - & - & - & - & - & - & - & - & - & - & - & - & - & + & + & - & - & - & - & + & + \\
\hline Palatal & - & - & - & - & + & + & - & - & - & - & - & - & - & - & - & - & - & - & - & - & - & - & - & - & - & - \\
\hline Velar & - & - & - & - & - & - & + & + & - & - & - & - & - & - & - & - & - & - & - & - & + & - & - & - & - & - \\
\hline $\begin{array}{l}\text { Labialized } \\
\text { Velar }\end{array}$ & - & - & - & - & - & - & - & - & - & - & + & + & - & - & - & - & - & - & - & - & - & - & - & - & - & - \\
\hline $\begin{array}{l}\text { Labiovela } \\
\text { r }\end{array}$ & - & - & - & - & - & - & - & - & + & + & - & - & - & - & - & - & - & - & - & - & - & - & - & - & - & - \\
\hline Glottal & - & - & - & - & - & - & - & - & - & - & - & - & - & - & - & - & - & - & - & - & + & - & - & - & - & - \\
\hline Plosives & + & + & + & + & + & + & + & + & + & + & + & + & - & - & - & - & - & - & - & - & - & - & - & - & - & - \\
\hline Fricatives & - & - & - & - & - & - & - & - & - & - & - & - & + & + & + & + & + & + & + & + & + & - & - & - & - & - \\
\hline Affricates & - & - & - & - & - & - & - & - & - & - & - & - & - & - & - & - & - & - & - & - & - & + & + & + & + & + \\
\hline Voicing & - & + & - & + & - & + & - & + & - & + & - & + & - & + & - & + & - & + & - & + & - & - & + & - & - & + \\
\hline
\end{tabular}

\section{Acoustic Study of Aro and Mgbo Obstruents}

\section{Variation in pitch measured in Hertz $(\mathrm{Hz})$}


TABLE 6.

VARIANCE IN MEAN AVERAGE PITCH LEVELS

\begin{tabular}{|c|c|c|c|c|c|}
\hline Aro & & Mgbo & & Standard Igbo & $\begin{array}{l}\text { English } \\
\text { gloss }\end{array}$ \\
\hline [àpàtà] & 155.3 & [ưtákú] & 145.1 & [àpàtà] & Thigh \\
\hline [ákpócōpó] & 183.2 & [ákp̄éhớ] & 152.5 & [ák̄kókpó] & Skin \\
\hline$\left[\mathrm{n} \int \mathrm{I}\right]$ & 203.5 & {$\left[\mathrm{n} \int \mathrm{I}\right]$} & 145.7 & {$\left[\mathrm{n} \int \mathrm{I}\right]$} & Faeces \\
\hline [úté] & 197.7 & [úté] & 165.9 & [úté] & Mat \\
\hline [àkpà] & 156.1 & [غ̇kpà] & 132.2 & [àkpà] & Bag \\
\hline [òwú] & 186.3 & [òwú] & 153.8 & [òwú] & Thread \\
\hline [òkpú] & 184.8 & [òk̂̄ú] & 165.9 & [òk̂̄ú] & Hat \\
\hline [ÉpitI] & 179.9 & [Épitı] & 160.7 & [áprtı] & Mud \\
\hline [ávò] & 223.3 & [áßá] & 148.2 & [áfỏ] & Year \\
\hline [ókwú] & 189.7 & [ópfú] & 177.6 & [ḿkpúrúókwú] & Word \\
\hline [mpì] & 169.6 & [ùpI] & 204.8 & [mpì] & Horn \\
\hline [mbé] & 193.1 & [mbéfú] & 192.3 & [ḿbé] & Tortoise \\
\hline [nfikó] & 181.7 & [ykò] & 164.1 & [nfikó] & Crab \\
\hline [úsứ] & 190.8 & [úbátsó] & 112.9 & [úsú] & Bat \\
\hline [mmádi] & 184.1 & [úmádò] & 148.7 & [mmádò] & Person \\
\hline [dí] & 175.6 & [dzí] & 149.6 & [dí] & Husband \\
\hline [mkpớmkpó] & 202.2 & [mkpírìji] & 184.1 & [mkpớmk̄oú] & Short \\
\hline [óvứú] & 132.5 & [ófứú] & 160.3 & [óhứró] & New \\
\hline [ndzó] & 180.9 & [nd3ó] & 155.1 & [ndzó] & Bad \\
\hline [ن̀tó] & 175.9 & [ùtsó] & 160.9 & [ùtó] & Sweet \\
\hline [biā] & 188.8 & [bj $\left.{ }^{j} \overline{\mathrm{I}}\right]$ & 144.1 & [bıā] & Come \\
\hline
\end{tabular}

The mean average pitch levels of some selected recorded tokens are presented here. The range of pitch levels in the dialect varieties is not the same. In Aro dialect, the highest pitch level reached is $223.3 \mathrm{~Hz}$ and the lowest is $132.5 \mathrm{~Hz}$. For Mgbo dialect, the highest pitch is $204.8 \mathrm{~Hz}$ and the lowest is $112.9 \mathrm{~Hz}$. It is of interest to note that vowels have effect on the pitch levels of the consonants with which they occur in the same environment. In this case, the pitch is raised where there should have been a pitch lowering.

\section{Variance in intensity measured in Decibel $(\mathbf{d b})$}

TABLE 7.

VARIANCE IN MEAN AVERAGE INTENSITY LEVELS

\begin{tabular}{|c|c|c|c|c|c|}
\hline Arọ & & Mgbo & & Standard Igbo & English gloss \\
\hline [àpàtà] & 72.1 & [ưtákú] & 74.2 & [àpàtà] & Thigh \\
\hline [ákpókpó] & 73.5 & [ákpéhó́] & 76.1 & [ákpókpó] & Skin \\
\hline$\left[\mathrm{n} \int \mathrm{I}\right]$ & 73.2 & {$\left[\mathrm{n} \int \mathrm{I}\right]$} & 73.9 & {$\left[\mathrm{n} \int \mathrm{I}\right]$} & Faeces \\
\hline [úté] & 77.9 & [úté] & 73.9 & [úté] & Mat \\
\hline [àkpà] & 76.4 & [غ̇k̄pà] & 74.2 & [àkpà] & Bag \\
\hline [òwú] & 80.1 & [òwú] & 75.2 & [òwú] & Thread \\
\hline [òkpú] & 78.1 & [òk̂ú] & 75.6 & [òk̂́pú] & Hat \\
\hline [غ́pıtI] & 75.8 & [غ́pitı] & 78.3 & [ápitI] & Mud \\
\hline [ávò] & 78.2 & [áßá] & 77.5 & [áfó] & Year \\
\hline [ókwú] & 76.5 & [ópfú] & 73.3 & [ḿkpúrúókwú] & Word \\
\hline [mpì] & 75.0 & [ن̀pI] & 73.5 & [mpì] & Horn \\
\hline [mbé] & 78.6 & [mbéfú] & 75.3 & [mbé] & Tortoise \\
\hline [njikó] & 72.1 & [yk’̀] & 73.2 & [njikó] & Crab \\
\hline [úsứ] & 73.5 & [úbátsứ] & 74.2 & [úsú] & Bat \\
\hline [mmádi] & 77.9 & [úmádò] & 73.5 & [mmádò] & Person \\
\hline [dí] & 75.1 & [dzí1] & 73.4 & [dí] & Husband \\
\hline [mkpúmk̄ón] & 75.7 & [mkpírìjî] & 71.1 & [mkpúmkpú] & Short \\
\hline [óvớrú] & 77.6 & [ófứú] & 75.3 & [óhứró] & New \\
\hline [ndzó] & 75.6 & [ndzó] & 76.6 & [ndzó] & $\mathrm{Bad}$ \\
\hline [ùtó] & 75.6 & [ùtsó] & 73.2 & [ờtó] & Sweet \\
\hline [bıā] & 80.9 & {$\left[\mathrm{~b}^{\mathrm{j}} \mathrm{I} \overline{\mathrm{a}}\right]$} & 76.0 & [bıā] & Come \\
\hline
\end{tabular}

The mean average intensity of some selected recorded tokens is presented here. As expected, the intensity in the dialect varieties is not the same, however, they do not differ as much as the variation in pitch levels. In Aro dialect, the highest intensity attained is $80.9 \mathrm{~dB}$ and the lowest is $72.1 \mathrm{~dB}$ (the same for two tokens). For Mgbo dialect, the highest intensity is $78.3 \mathrm{~dB}$ and the lowest is $71.1 \mathrm{~dB}$.

\section{Variance in duration measured in seconds}


TABLE 8.

VARIANCE IN MEAN AVERAGE DURATION LEVELS

\begin{tabular}{|c|c|c|c|c|c|}
\hline Arọ & & Mgbo & & $\begin{array}{l}\text { Standard } \\
\text { Igbo }\end{array}$ & $\begin{array}{l}\text { English } \\
\text { gloss }\end{array}$ \\
\hline [àpàtà] & 0.514 & [ớtákú] & 0.614 & [àpàtà] & Thigh \\
\hline [ákpók̂́kó] & 0.618 & [ákpéhó'] & 0.431 & 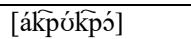 & Skin \\
\hline$\left[\mathrm{n} \int \mathrm{I}\right]$ & 0.564 & {$\left[\mathrm{n} \int \mathrm{I}\right]$} & 0.402 & {$\left[\mathrm{n} \int \mathrm{I}\right]$} & Faeces \\
\hline [úté] & 0.507 & [úté] & 0.502 & [úté] & Mat \\
\hline [àkpà] & 0.469 & [غ̇k̄ pà] & 0.499 & [àkpà] & $\mathrm{Bag}$ \\
\hline [òwú] & 0.550 & [òwú] & 0.496 & [òwú] & Thread \\
\hline [òkpú] & 0.540 & [òkpú] & 0.414 & [òkpú] & Hat \\
\hline ['́pitI] & 0.602 & ['́pitI] & 0.546 & [ápitI] & Mud \\
\hline [ávò] & 0.489 & [áßá] & 0.573 & [áfò] & Year \\
\hline [ókwú] & 0.547 & [ópfú] & 0.494 & [ḿkêúrúókwú] & Word \\
\hline [mpì] & 0.503 & [ùpI] & 0.398 & [mpì] & Horn \\
\hline [mbé] & 0.392 & [mbéfú] & 0.514 & [mbé] & Tortoise \\
\hline [nfikó] & 0.632 & [nkj̀] & 0.395 & [nfikó] & Crab \\
\hline [úsó] & 0.544 & [úbátsú] & 0.698 & [úsó] & Bat \\
\hline [mmádi] & 0.586 & [úmádò] & 0.594 & [mmádò] & Person \\
\hline [dí] & 0.354 & [dzí] & 0.380 & [dí] & Husband \\
\hline [mk̄pómk̄pó] & 0.764 & [mkpírìjî] & 0.684 & [mk̄pómk̄pó] & Short \\
\hline [óvơró] & 0.593 & [ófớú] & 0.734 & [óhớró] & New \\
\hline [ndzó] & 0.566 & [ndzó] & 0.542 & [ndź́] & $\mathrm{Bad}$ \\
\hline [ò̀tó] & 0.525 & [ờtsó] & 0.473 & [òtó] & Sweet \\
\hline [bıā] & 0.384 & [bं $\left.{ }^{\mathrm{j}} \overline{\mathrm{a}}\right]$ & 0.299 & [bıā] & Come \\
\hline
\end{tabular}

The mean average duration of some selected recorded tokens is presented here. The period of production in the dialect varieties is not the same. In Arọ Igbo dialect, the highest duration for production is $0.764 \mathrm{~s}$ and the lowest is $0.354 \mathrm{~s}$. For Mgbo dialect, the highest duration is 0.698 sand the lowest is $0.299 \mathrm{~s}$. The differences that occur in the period or duration of production are as a result of the length of individual tokens.

\section{E. Acoustic Analysis of Selected Aro and Mgbo Obstruents}

The duration, mean intensity and mean pitch was measured from spectrograms of the tokens collected. The closure and burst duration of stops, the formant frequencies for all the tokens were also measured. The female respondents presented higher frequencies because of their vocal cords anatomy which is smaller than their male counterparts. The formant transition values which were calculated were not compared across the dialects.

Consonants are measured in terms of their intensity, weakness or strength. Stops are the strongest and fricatives are the weakest. Obstruents are generally characterized by a combination of intervals of noise, silence and changing formant transitions. The articulation of stops consists of; a brief modulation between the preceding vowel and the plosive, a period of total closure, a vocal burst or release and an interval of transitions from the stop into the following vowel or approximant. The period of burst is usually very brief, with energy across the spectrum. Unreleased stops do not show a burst. It has been established in sound analysis that the most crucial thing, as regards voicing is the low frequency at the base of the spectrogram in the frequency range from 0 to around $200 \mathrm{~Hz}$. The darker areas in the spectrogram indicate voicing and are referred to as voicing bar.

\section{F. Spectrographic Analysis}

In this section, spectrograms to show the waveforms for some of the peculiar features of some selected obstruents in Arọ and Mgbo will be presented. 


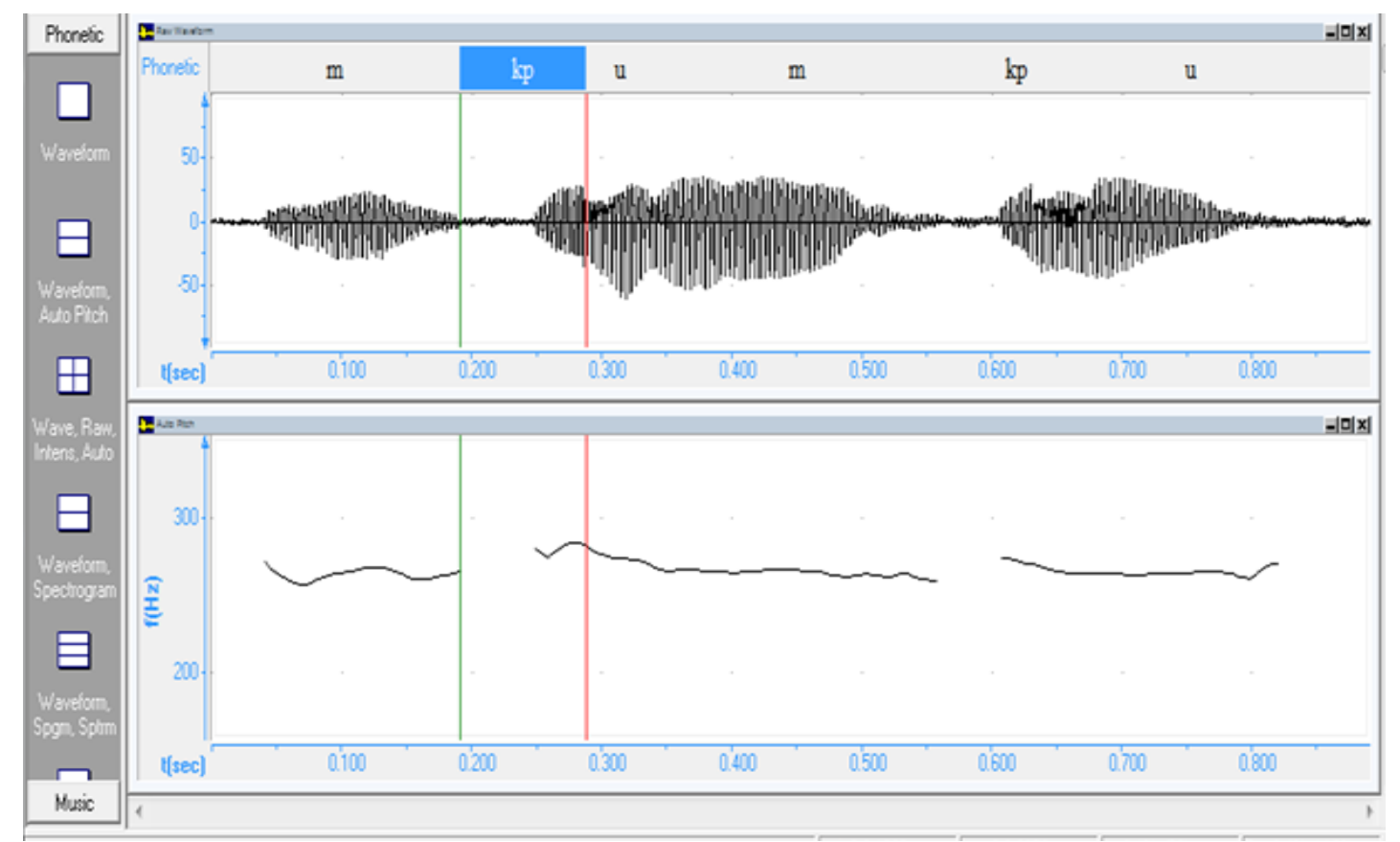

Fig 1. Showing wave form and spectrogram for Arọ word [mk̂́ómk̂́ú] 'short'

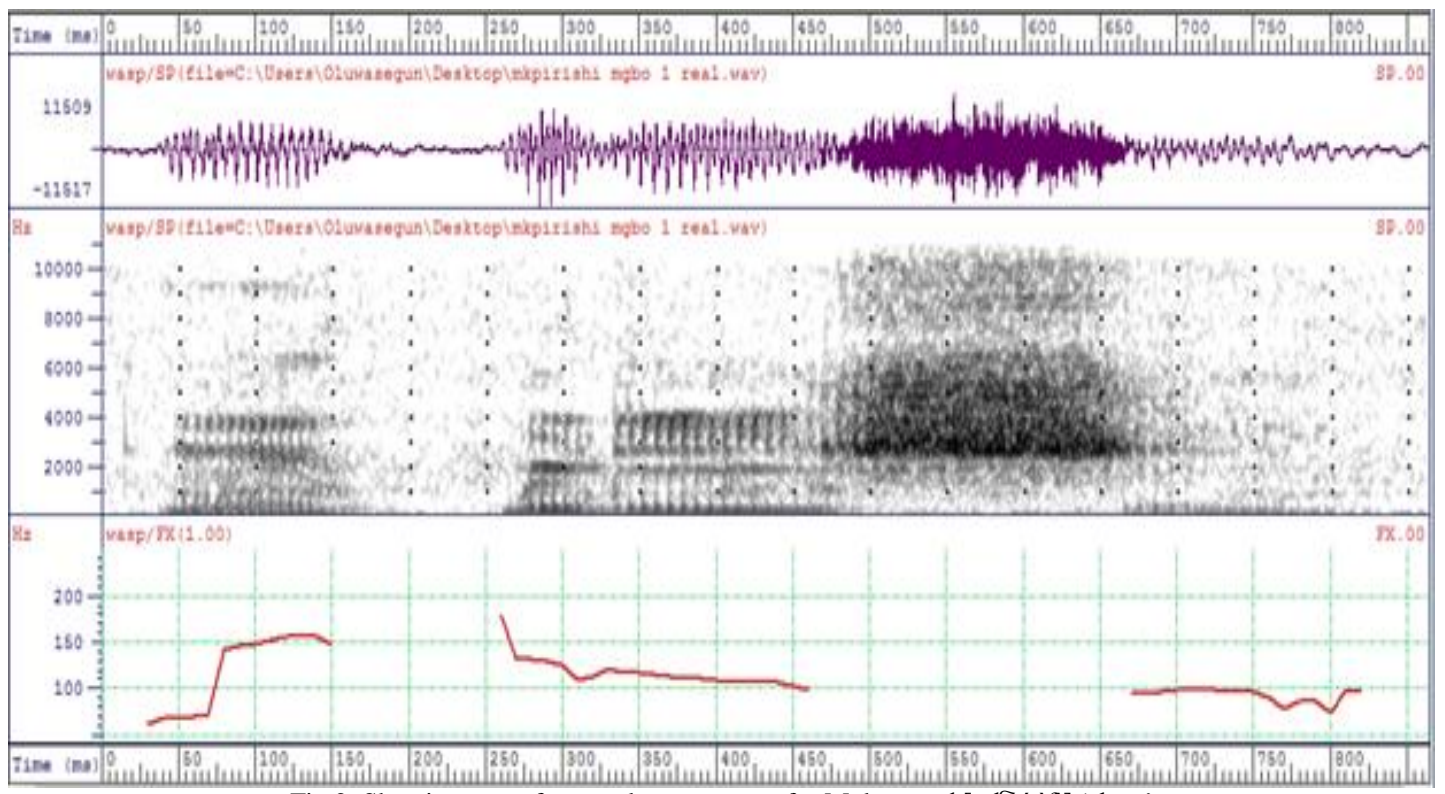

Fig 2. Showing wave form and spectrogram for Mgbo word [mkpírìi] 'short'

From the spectrogram, it is seen that in the production of the initial voiceless labio-velar plosive / $/ \mathrm{kp} /$ in Arọ, there is a strong vertical spike which shows the release burst. The period of closure from the onset time is approximately 0.08 seconds and the release burst is about 0.06 seconds. For the initial voiceless labio-velar plosive $/ \widehat{\mathrm{kp}} /$ in $\mathrm{Mgbo}$ dialect [mkpírìj], there is also a strong vertical spike for the release burst. The period of closure is a bit longer than that of Aro at 0.09 seconds and the burst was recorded at 0.04 seconds. The VOT is negative and there is no voice bar. The acoustic energy occurred at high frequency, almost above $5500 \mathrm{~Hz}$ (as is usual for fricatives) and the turbulence noise is stronger for $/ \mathrm{J} /$ - sh, however, the intensity is low at almost $2500 \mathrm{~Hz}$ (one of the characteristic features of post-alveolar consonants). There is a change in the formant frequency pattern of $/ \mathrm{kp} /$ which transitions in time for the preceding vowel sound. 


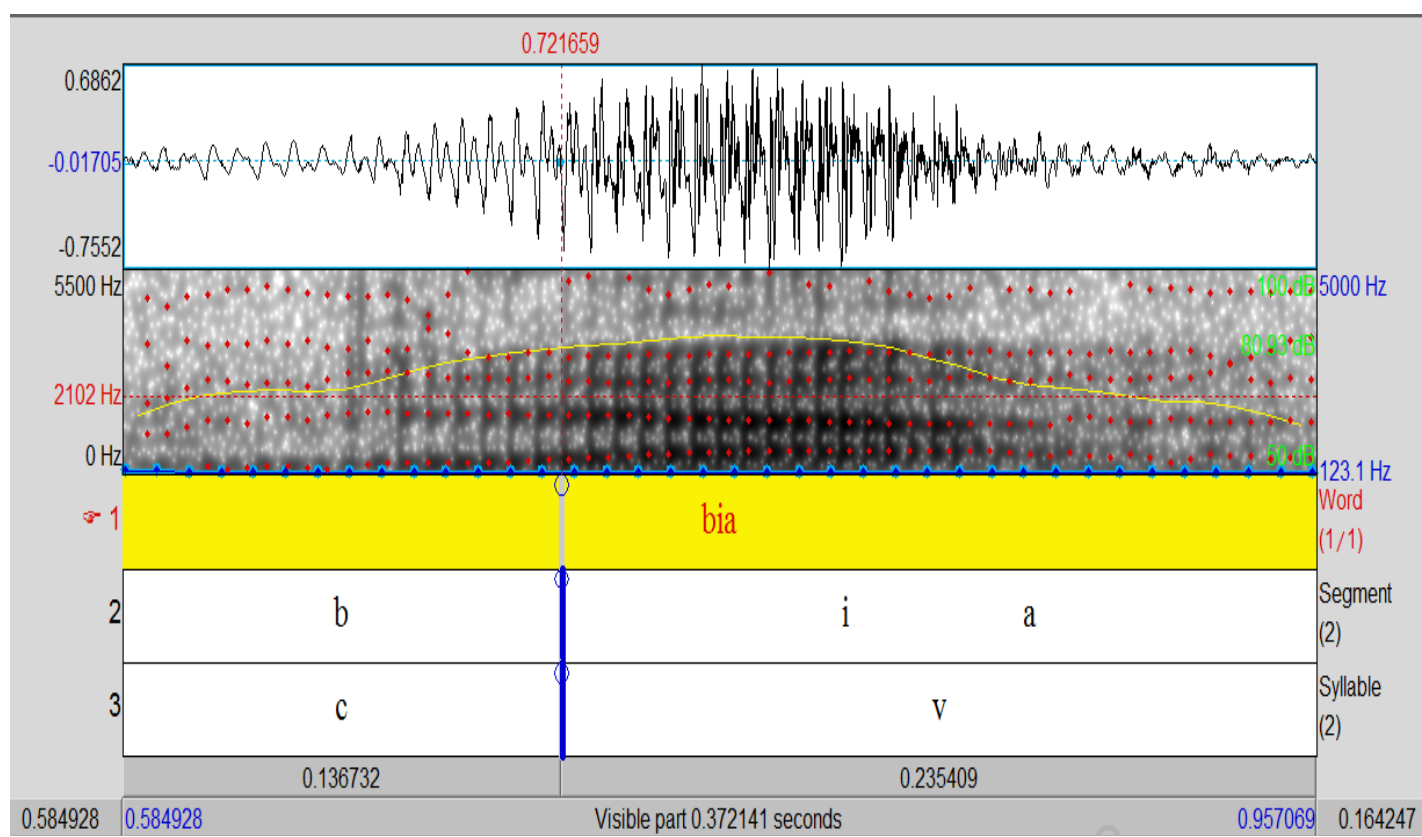

Fig 3. Showing wave form and spectrogram for Arọ word [bia] 'come'

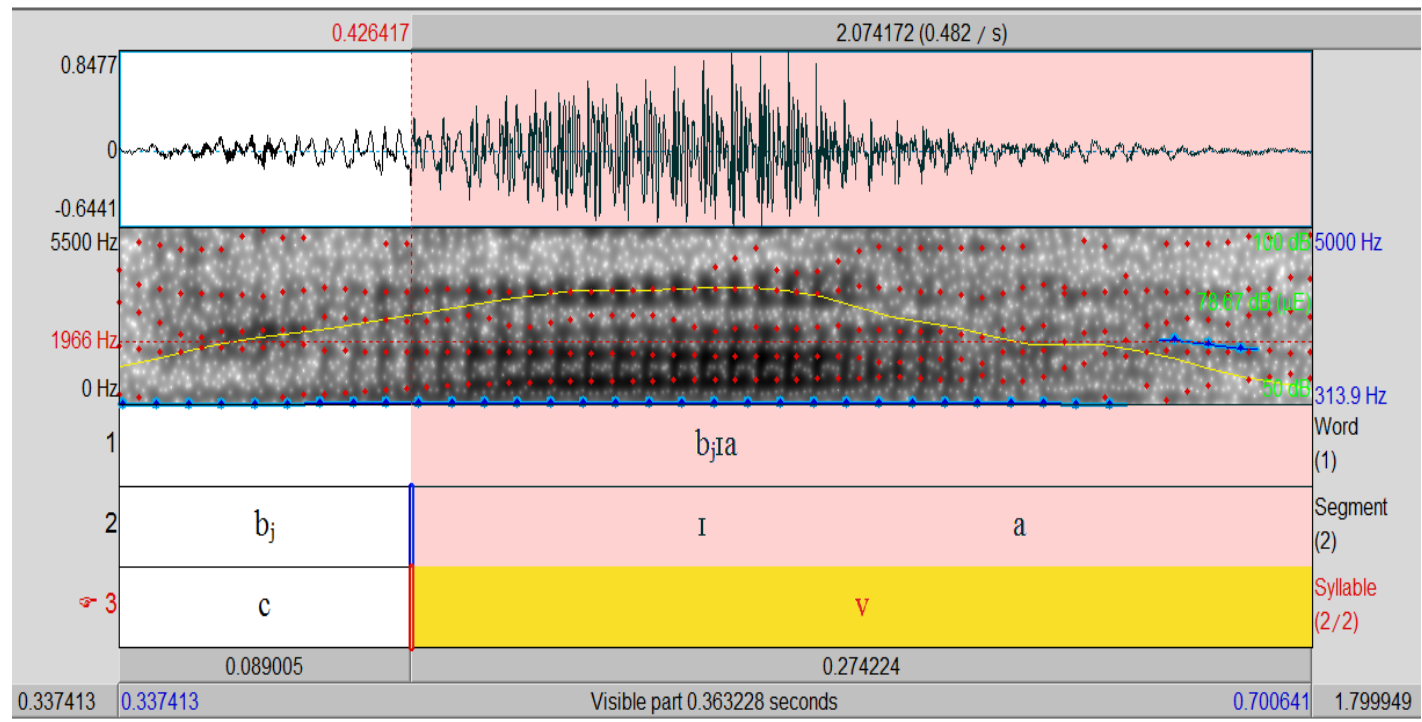

Fig 4. Showing wave form and spectrogram for Mgbo word [bja] 'come'

In Arọ dialect, the production of [bra] has a very thick voicing bar. There is a noticeable vertical spike at the release stage of the voiced bilabial plosive /b/, however, the VOT is positive with a high intensity noise of about $3300 \mathrm{~Hz}$. The duration for the production of this obstruent is 0.13 seconds while the duration for the entire word is 0.37 seconds. For Mgbo [ $\mathrm{b}^{\mathrm{j}} \mathrm{a}$ ], the voicing bar for $/ \mathrm{b} /$ is thick and there is a strong vertical spike at the release stage. The VOT is positive and the burst energy is below $1000 \mathrm{~Hz}$. The duration for the production of this palatalized bilabial plosive is 0.08 seconds while for the whole segment is 0.36 seconds. It can be deduced that the duration for the obstruents in Aro is slightly longer than its palatalized counterparts in Mgbo. There is significant relationship between the amplitude values of the word [bia] in the two dialects. While the maximum amplitude value for the word in Aro is 0.99Pascal that of Mgbo presents a value of 0.90 Pascal. The wave form and intensity is almost the same across the dialects. The voiced bilabial plosive is produced with the compression of the lips. 


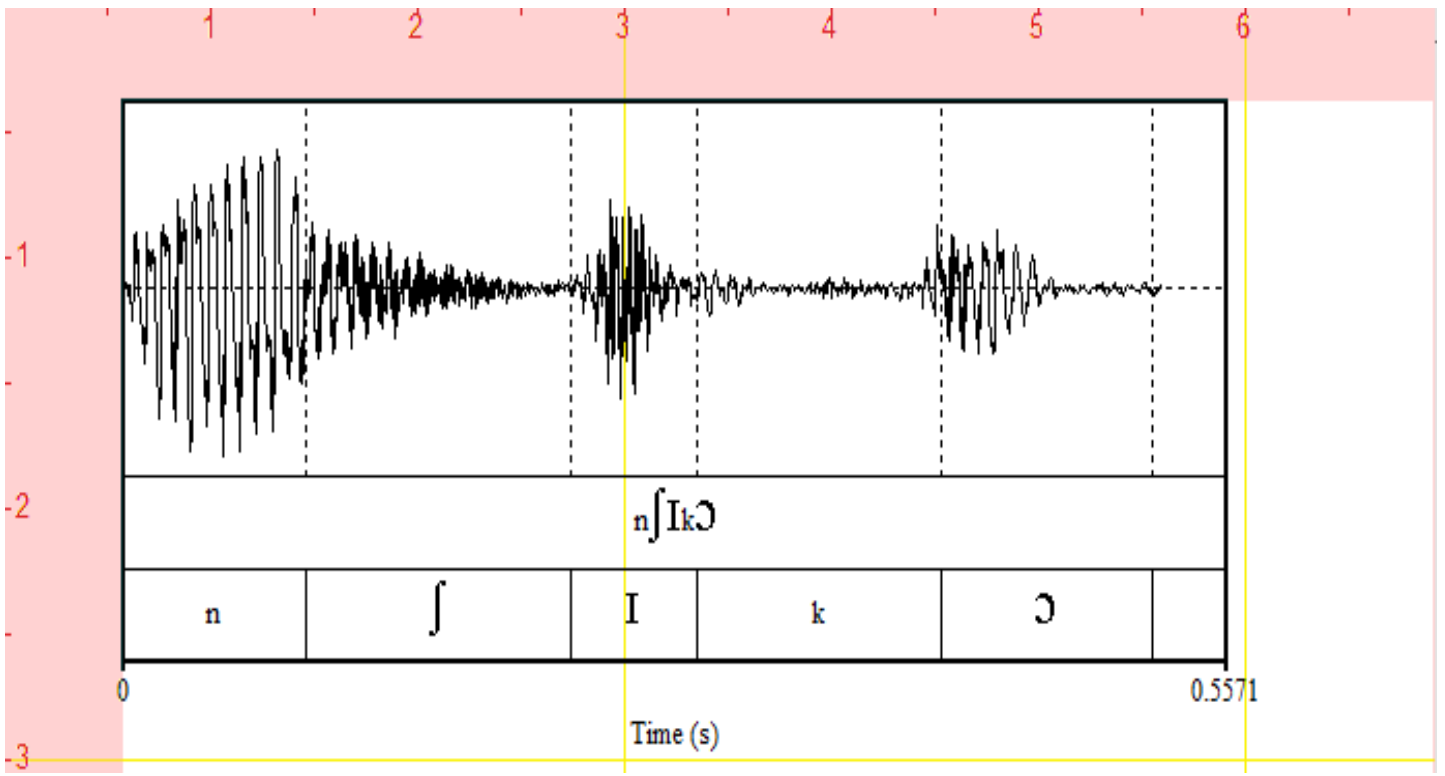

Fig 5. Showing wave form and spectrogram for Arọ word [n]ikb́] 'crab'

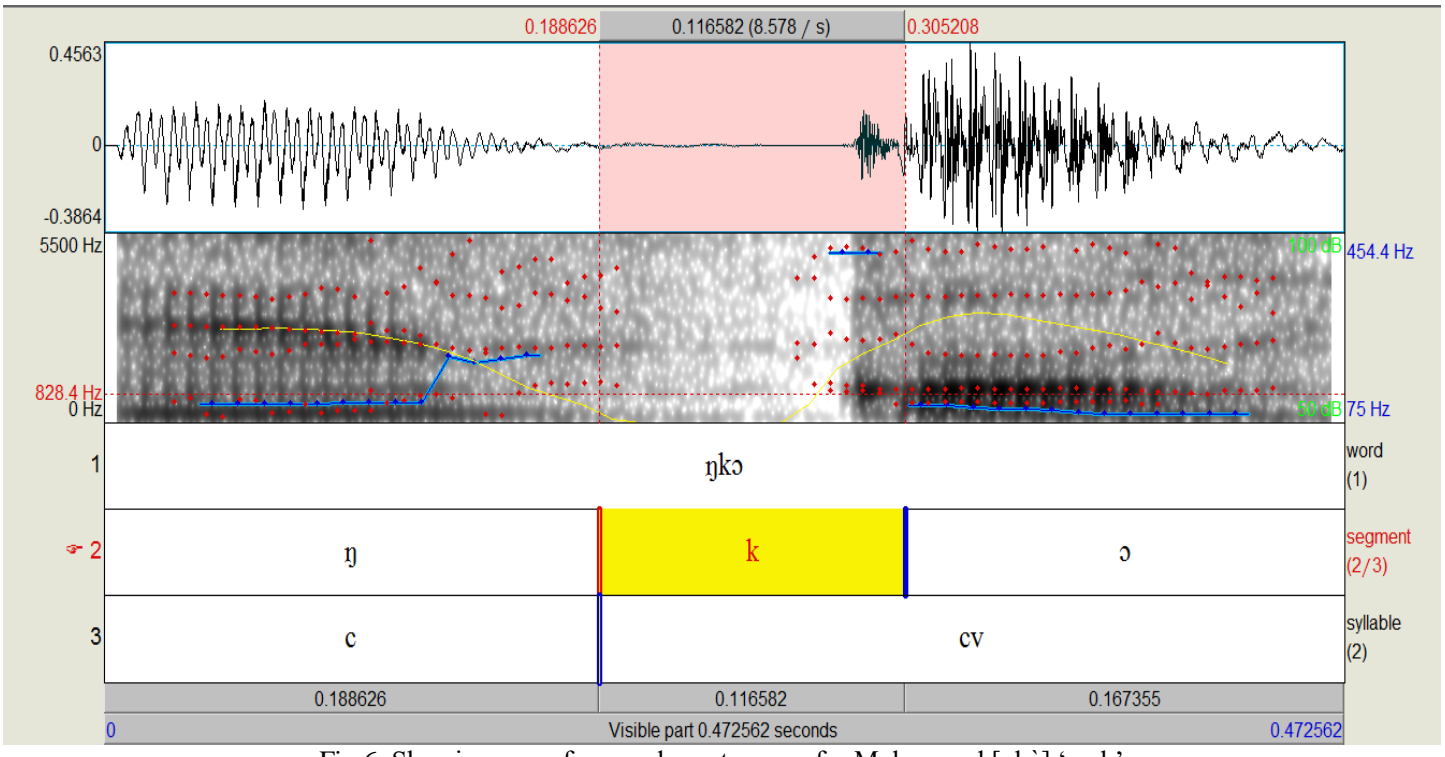

Fig 6. Showing wave form and spectrogram for Mgbo word [nkj̀] 'crab'

The voiceless velar plosive $/ \mathrm{k} /$ is produced with the compression of the back of the tongue against the back of the roof of the mouth. The length of the duration of the production of [nfikb́] in Aro is 0.55 seconds. The duration of the closure stage is 0.05 seconds and the release burst is only 0.03 seconds. There is no voicing bar for the production of voiceless velar plosive $/ \mathrm{k} /$ and a strong vertical spike at the release stage is evinced. The turbulence noise is stronger in $/ \mathrm{J} /$ and the acoustic energy occurred at a higher frequency. The intensity is $70.65 \mathrm{~dB}$ and there is an aperiodic spread of sound over part of the spectrum. The maximum amplitude level is $0.26 \mathrm{Pascal}$. For the production of [ykj] in Mgbo, the maximum amplitude is rated at 0.45 Pascal. The duration for the production of the entire word is 0.47 seconds while the individual $/ \mathrm{k} /$ sound was produced at 0.11 seconds. There is also no voicing bar for this velar plosive and the VOT is negative. However, there is a strong vertical spike indicating release burst. There is also a visible change in the formant pattern that shows the transition for the preceding back rounded vowel $/ \mathrm{s}$. The intensity for the velar plosive is below $800 \mathrm{~Hz}$ across the two dialects. 


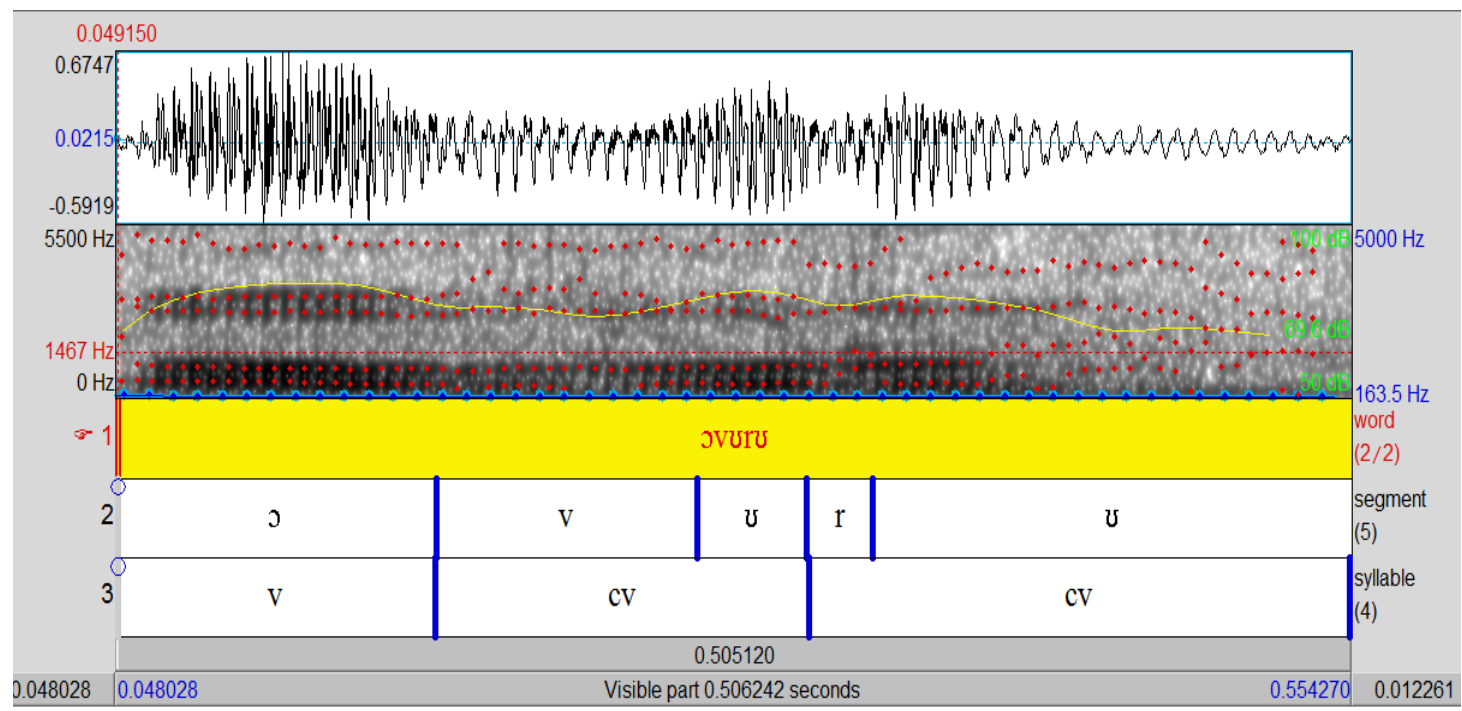

Fig 7. Showing wave form and spectrogram for Arọ word [óvớró] 'new'

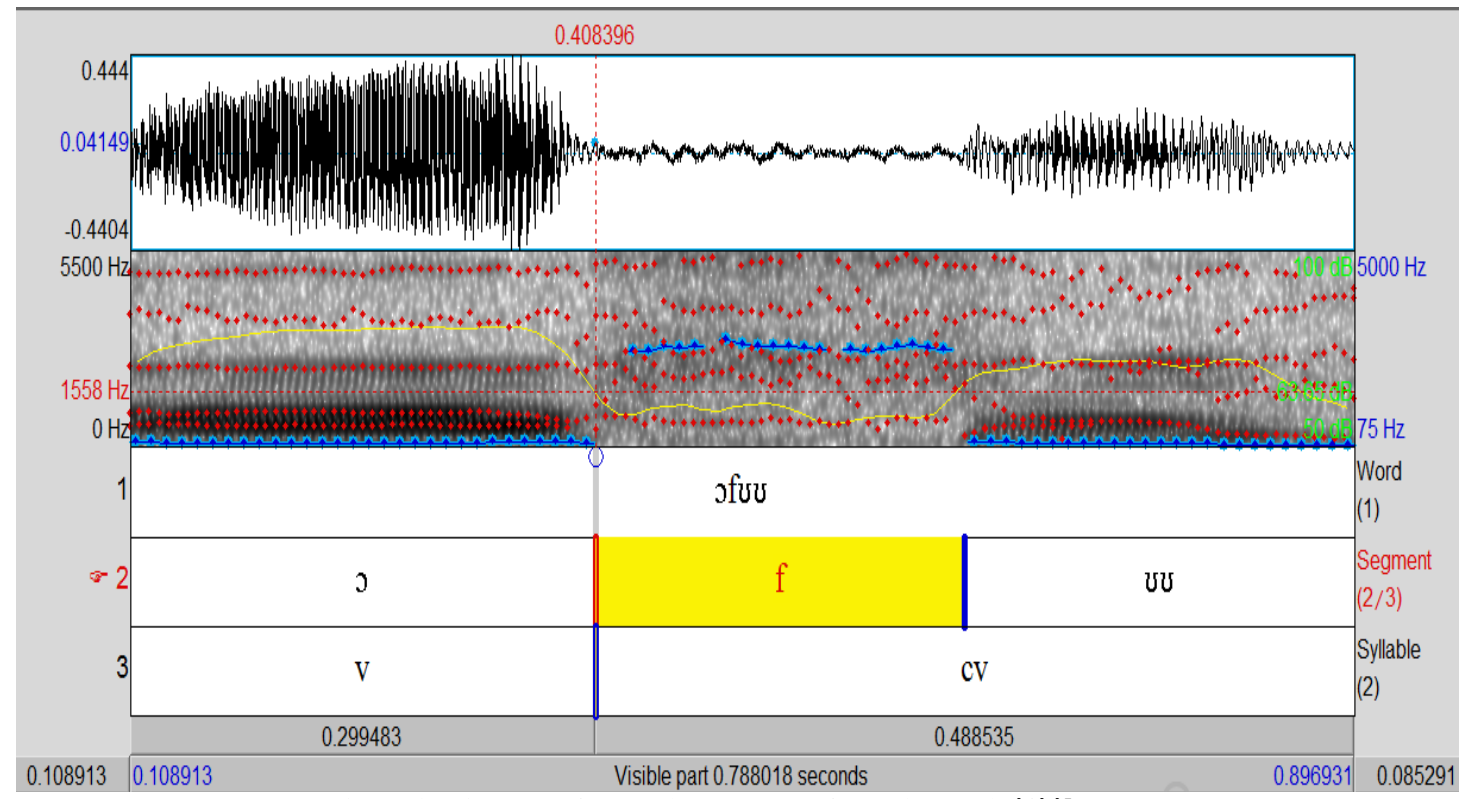

Fig 8. Showing wave form and spectrogram for Mgbo word [ófớu' 'new'

The voicing bar for the production of the voiced labio-dental fricative / $/$ in Arọ [óvớrú]is low at approximately $400 \mathrm{~Hz}$. Although it has a higher formant than its voiceless counterpart in [ófớ], the intensity is below 100dB. With maximum amplitude of 0.67Pascal, the voiced fricative showed aspects of both regular vocal fold vibrations and a randomly turbulent airstream. While the duration of the voiced fricative is 0.07 seconds, the total duration for the word [óvứró] is 0.50seconds. The maximum amplitude for [ófớu in Mgbo is 0.44Pascal and the /f/ presents high frequency turbulence between $3000-4000 \mathrm{~Hz}$. This voiceless fricative has a weaker formant than the voiced labio-dental fricative. The intensity is below $100 \mathrm{~dB}$, however, there is an aperiodic spread of sound over part of the spectrum. 


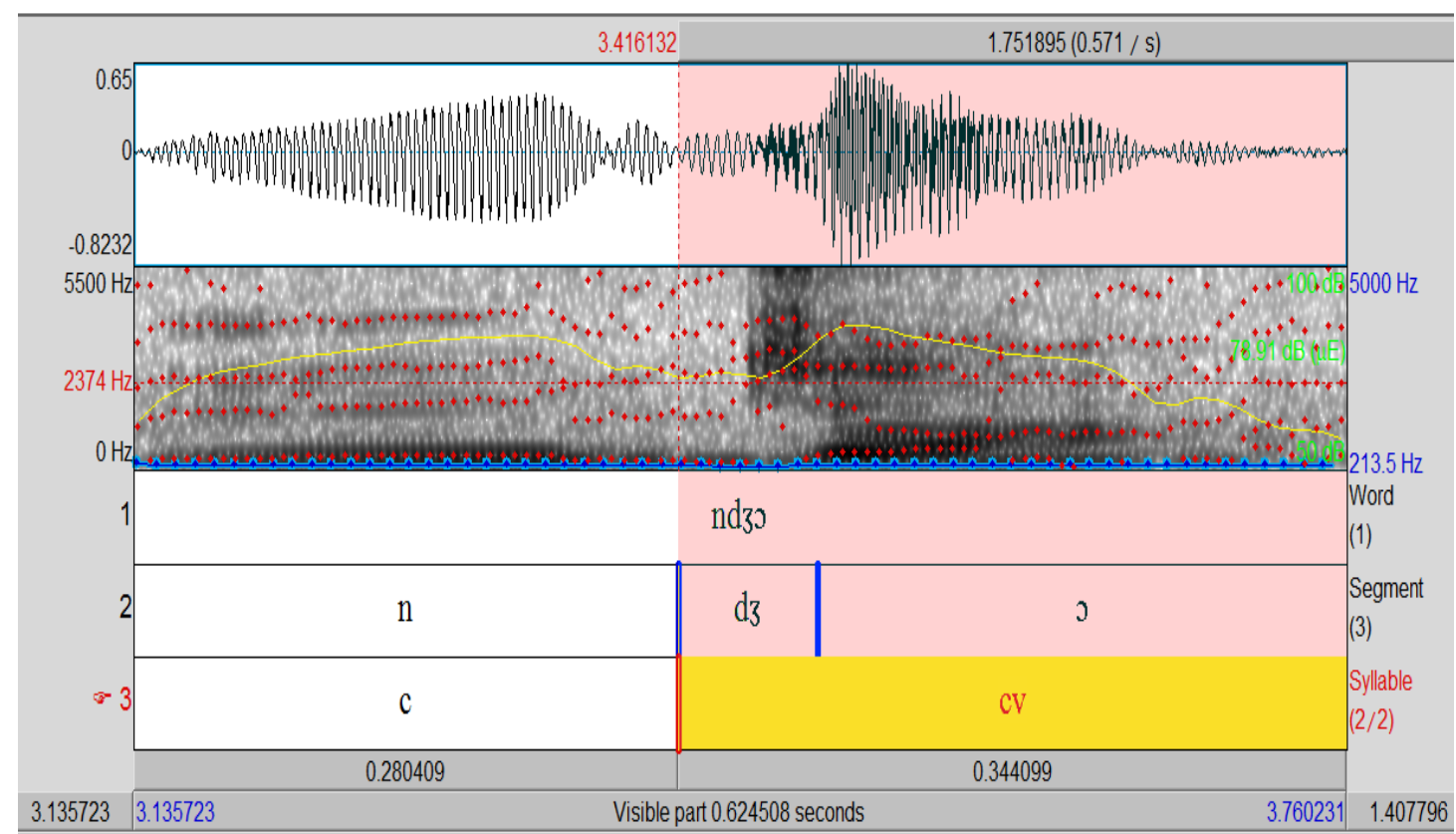

Fig 9. Showing wave form and spectrogram for Arọ word [ndzó] 'bad'

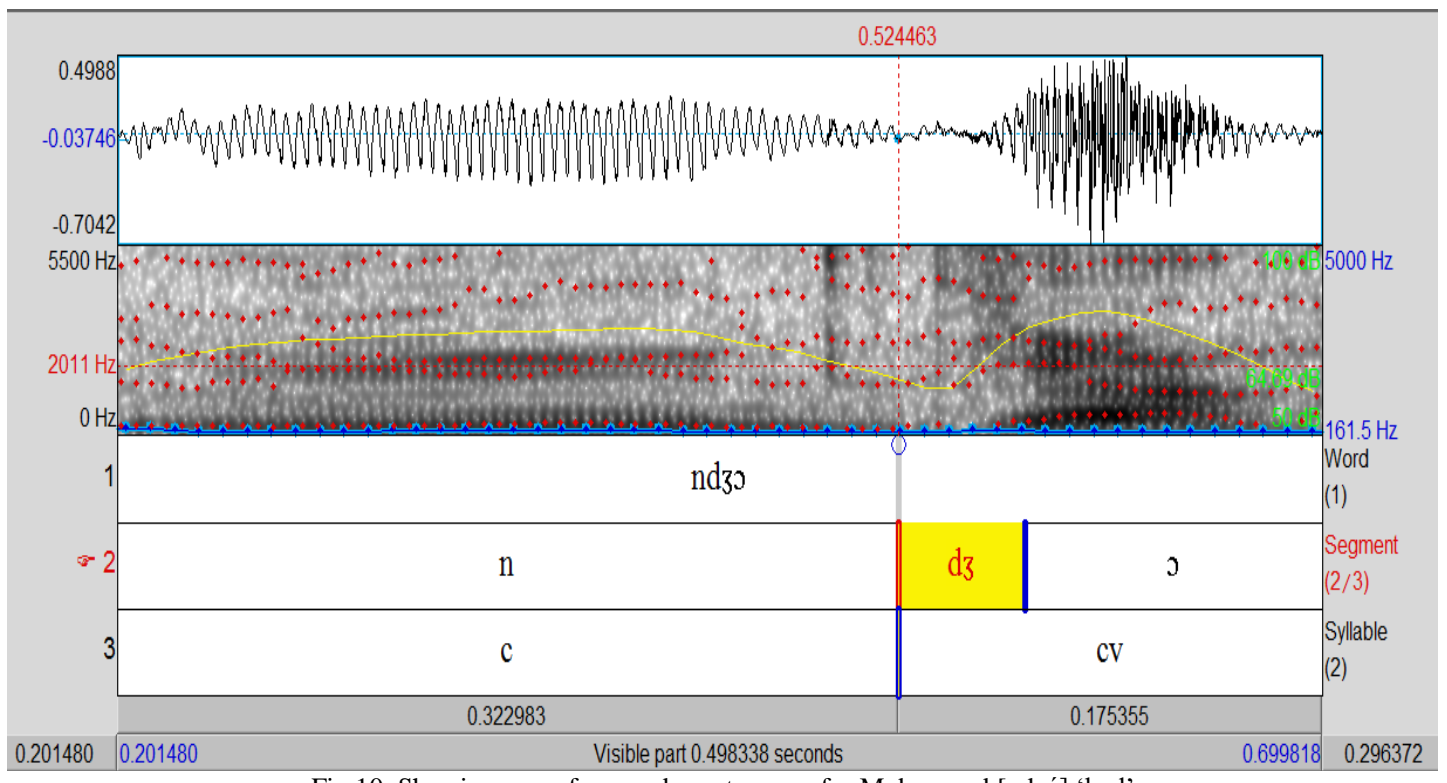

Fig 10. Showing wave form and spectrogram for Mgbo word [ndz’́] 'bad'

In [ndz'́] for Aro and Mgbo, there is a voice lag from the initial alveolar nasal onto the voiced post-alveolar affricate $/ \mathrm{d} 3 /$. The release is noisy and the formant information for the affricate is slightly above $2100 \mathrm{~Hz}$ in Aro and below $2000 \mathrm{~Hz}$ in Mgbo. The duration for the production of the word is 0.34 seconds in Aro and 0.49seconds in Mgbo. This slight difference in the duration occurred because of speech variance and the initial nasal in the Mgbo word is longer than that of Arọ. The given maximum amplitude in the Arọ word is 0.82Pascal and 0.49Pascal in the Mgbo word. 


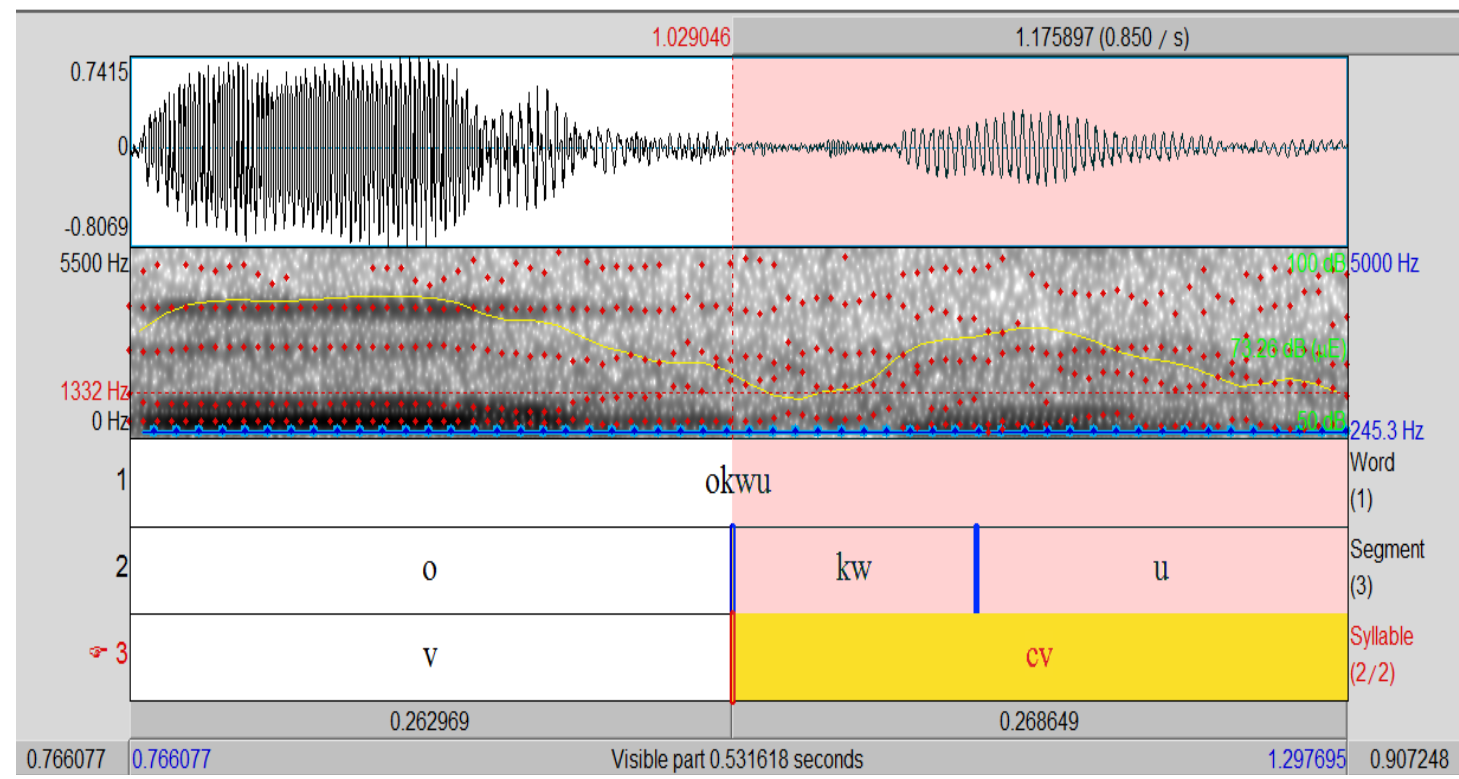

Fig 11. Showing wave form and spectrogram for Arọ word [okwu] 'word'

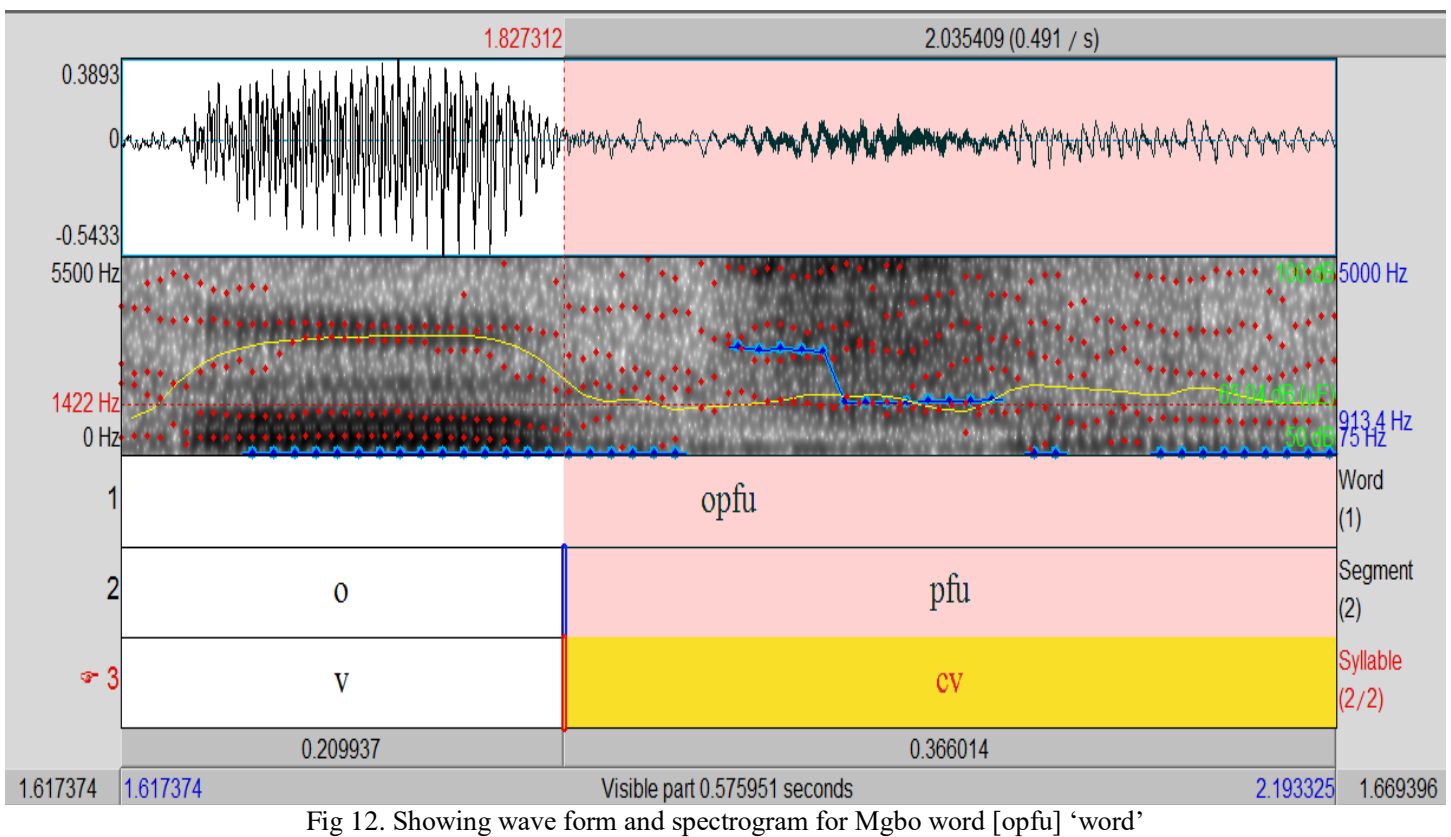

In the production of [okwu] in Arọ, there is no voicing bar for $/ \mathrm{kw} /$. However, there is a vertical spike at the release stage. The period of closure is 0.12 seconds and burst lasts for only 0.07 seconds. This pre-vocalic stop has a formant frequency which transforms for a period of time after the stop is released, during the beginning of the preceding vowel sound. There is a noticeable rise in pitch in the production of the final vowel sound / $\mathrm{u} / \mathrm{unlike}$ that of Mgbo. This is called transition and this rise is as a result of the labiolized velar plosive. The total word production duration is 0.431 seconds. For [opfu] in Mgbo, there is a rise in the pitch level at the production of /o/ followed by a downward movement connoting a decrease in pitch level as is shown on the spectrogram. However, the final back rounded vowel sound $/ \mathrm{u} / \mathrm{is}$ not prominent because it pitters out in the production. This suggests the existence of codas in the dialects of Mgbo. 


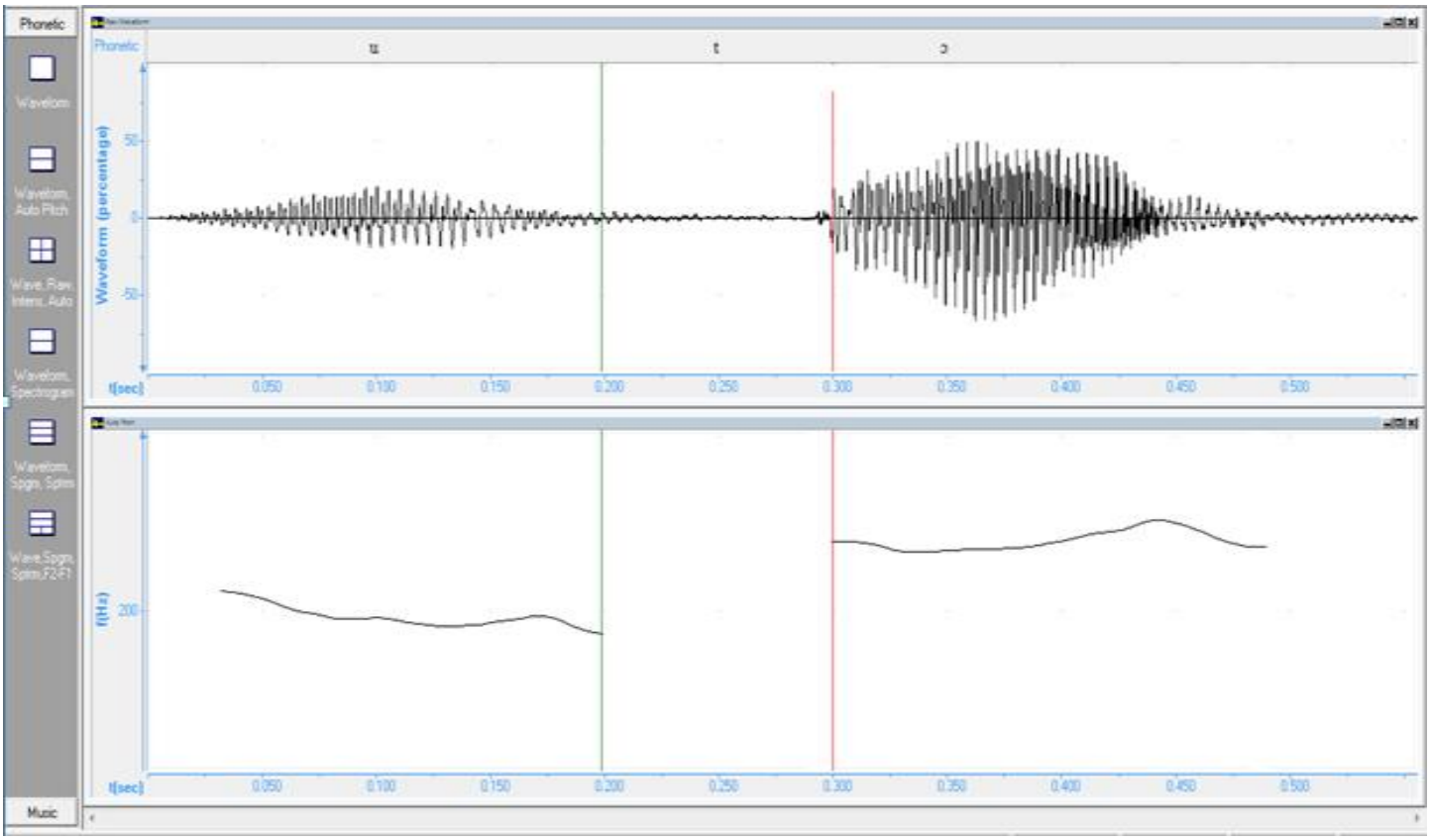

Fig 13. Showing wave form and spectrogram for Arọ word [òtó] 'sweet'

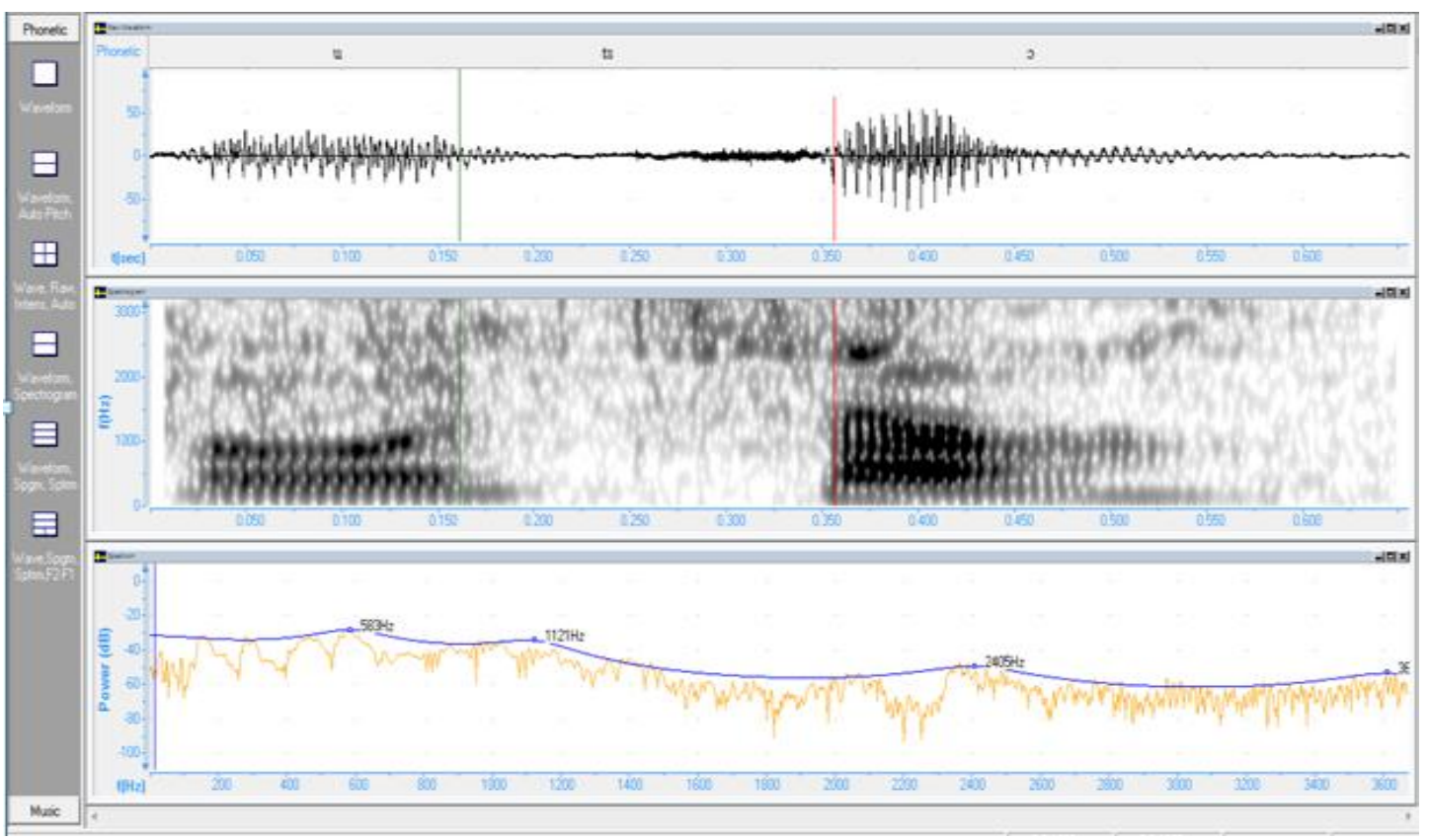

Fig 14. Showing wave form and spectrogram for Mgbo word [òtsó] 'sweet'

For Arọ, there is no voicing bar for /t/. This voiceless alveolar plosive shows characteristics of unreleased stops, however, there is no strong vertical spike as is usual for unreleased plosives because of the last back rounded vowel /\%/. For the Mgbo production of [ùtsó], the /ts/ is not phonetically evinced because of the preceding and succeeding vowels.

\section{SUMMARY OF THE FINDINGS AND CONCLUSION}

\section{A. Summary of the Findings}

From the field work, we found out that Aro dialect is made up of twenty-eight consonants /p/, /b/, /t/, /d/, /k/, /g/, /kw/, /gw/, /kp/, /gb/,/m/, /n/, /n/, /g/, /nw/,/f/, /v/, /s/, /z/, /f/,/z/, /h/, /tf/, /dz/, /l/, /j/, /w/, /r/, while Mgbo dialect has

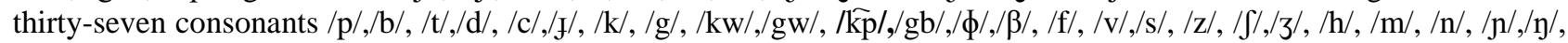
/nw/, /pf/,/bv/,/ts/, /dz/, /t $\mathrm{f} / / \mathrm{d} 3 /, / 1 /, / \mathrm{w} /, / \mathrm{j} / / / \mathrm{r} /, / \mathrm{w} /$.

The obstruents in the dialects of Arọ are nineteen /p/, /b/, /t/, /d/, /k/, /g/, /kw/, /gw/, / / $/, / g b /, / f /, / v /, / s /, / z /, / \mathrm{s} /, / 3 /$, /t $\mathrm{j} /, / \mathrm{d} z /, / \mathrm{h} /$ while Mgbo obstruents are twenty-seven /p/,/b/, /t/,/d/, /c/,/J/, /k/, /g/, /kw/,/gw/, /kp/,/gb/,/\$/,///, /f/, /v/,/s/, /z/, /J/,/3/, /h/, /pf/,/bv/,/ts/, /dz/, /t $/, / \mathrm{d} z /$. 
In the production of the word [mpi] by the Aro respondents, we realized that when there are nasal initial syllables followed by an obstruent, the voicing for the nasal spills over to the voiceless onset and render it voiced and the release of the burst assimilates or spills into the nucleus especially when it is the high front vowel. We also discovered, on the spectrogram, that voicing spread occurs from the voiced bilabial nasal to the voiceless bilabial plosive. A long bilabial closure for the nasal $/ \mathrm{m} /$ gave rise to a very short closure of the voiceless bilabial plosive and release. The final front high vowel /i/ is almost devoiced because of the explosion from the voiceless bilabial plosive. In the production the word [mmadị] in Arọ, the voiced alveolar plosive /d/ encroaches and superimposes on the preceding front high vowel /ị/ and almost devoices it. When producing [n $\left.\int_{\mathrm{I}}\right]$ across the three dialects, the front high vowel is devoiced because of the preceding voiceless palato-alveolar fricative.

We also discovered that in an environment where the labio-velar plosive occurs twice, only the second appearance is evinced in rapid speech, hence the first appearance is deleted as in the production of /akpụkpo ahụ/. It was also discovered that in an environment where the alveolar roll / $\mathrm{r}$ / occurs at the word medial, it is evidently produced in rapid speech however, in the acoustic analysis, it is not evinced. Across the dialects, the voiced bilabial plosive /b/ is shortened and the preceding vowels are produced together as there is no evident disparity between the vowels on the spectrogram. In environments where the alveolar roll /r/ occurred word medially, the sound is usually not evinced in the collective production of the word and on the spectrographic analysis. This is shown in the spectrograph of [mkpirifi] in

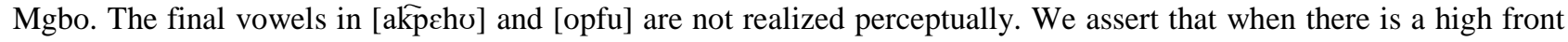
vowel followed by a voiceless plosive, the voicing of the vowel does not come to an abrupt end till somewhere just before the burst of the plosive. In word medial, /k/ does not have moments of closure and burst. All vowels are more prominent in acoustic analysis than their consonant counterparts.

From the acoustic analysis, we deduce that the pitch levels, intensity and period of production (duration) across the dialects varieties are noticeably varied. In Arọ dialect, the highest pitch level reached is $223.3 \mathrm{~Hz}$ and the lowest is $132.5 \mathrm{~Hz}$. For Mgbo dialect, the highest pitch is $204.8 \mathrm{~Hz}$ and the lowest is $112.9 \mathrm{~Hz}$. We also found out that the intensity in the dialect varieties is not the same, however, they do not differ as much as the variation in pitch levels. In Aro dialect, the highest intensity attained is $80.9 \mathrm{~dB}$ and the lowest is $72.1 \mathrm{~dB}$ (the same for two tokens). For Mgbo dialect, the highest intensity is $78.3 \mathrm{~dB}$ and the lowest is $71.1 \mathrm{~dB}$. Finally, the average duration of the period of production in the dialect varieties is not the same. In Aro dialect, the highest duration for production is $0.764 \mathrm{~s}$ and the lowest is $0.354 \mathrm{~s}$. For Mgbo dialect, the highest duration is $0.698 \mathrm{~s}$ and the lowest is $0.299 \mathrm{~s}$. The differences that occur in the period or duration of production are as a result of the length of individual tokens.

\section{B. Conclusion}

This paper is an acoustic comparison of obstruents in Aro and Mgbo dialects of the Igbo language. We looked at their pitch, intensity and duration and we have discovered that the obstruents across the two dialects are related to a large extent. We discovered that the two dialects have the syllable structures, V, CV, while the CVC structure is only exclusive to Mgbo. It may be concluded that in some Mgbo words, the last vowel is not produced because of the preceding lengthy consonants (obstruents). The evidence of perceptual result which is further confirmed by the acoustic result of the occurrence of closed syllables in the Mgbo dialect and the consonant clusters in these Abankaleke dialects cluster further gives credence to the fact that there are consonant clusters and closed syllables in the Igbo language. In most Northern Igbo (Waawa) dialects, back rounded vowels are weakened as is evinced in [nyəkə] and [ $\mathrm{\eta} k$ o]. The final vowels are so weak that they are not phonetically interpretable. The vowels are evident in the syllable structure because Igbo language does not operate a closed syllable structure. Finally, this study further gives credence to the fact that acoustic analysis is indispensable in any prosodic study in linguistic inquiry.

\section{REFERENCES}

[1] Chomsky, N. \& Halle, M. (1968). The sound pattern of English. New York: Harper and Row.

[2] Donwa I. S. (1995). Basic phonetics. Port-Harcourt: Sunray Publications.

[3] Fant, G. (1960). Acoustic theory of speech production. The Hague: Mouton.

[4] Hall, T. A. (2007). Segmental features. The Cambridge Handbook of Phonology, 10(1), 311-334.

[5] Ikekeonwu, C. I. (1986). A lexico-phonotactic study of Northern Igbo dialects. PhD thesis, University of Nigeria, Nsukka.

[6] Jongman, A. (2010). Acoustic phonetics. Oxford: Oxford University Press. https://kuppl.ku.edu/sites/kuppl.ku.edu/files/docs/Acoustic\%20Phonetics.pdf.

[7] Ladefoged, P.\& Maddieson, I. (1996). The sounds of the world's languages. Oxford: Blackwell.

[8] Liberman, A. M., Delattre, P., Cooper, F. S.\& Gerstman, L. J. (1952). An experimental study of the acoustic determinants of vowel color; observations on one-and two-formant vowels synthesized from spectrographic patterns. Word, 8(3), 195-210.

[9] Mannell, R. (2008). Distinctive features. Macquarie University.

[10] Mbah, B. M. \& Mbah, E. E. (2010). Topics in phonetics and phonology: Contributions from Igbo. Nsukka: AP Express Publishers.

[11] Mbah, B. M. (2016). Theories of linguistics. Nsukka: University of Nigeria Press Ltd.

[12] Nissen, S. L. (2003). An acoustic analysis of voiceless obstruents produced by adults and typically developing children. PhD thesis, The Ohio State University. http://www.ohiolink.edu/etd/send-pdf.cgi?osu1041225568.

[13] Nwaozuzu, G. I. (2008). Dialects of the Igbo language. University of Nigeria Press Ltd.

[14] Obianika, E. C. (2012). Interface of tone and morpheme in Abankaleke Igbo. PhD thesis, University of Nigeria, Nsukka. 
[15] Pisoni, D. B. (1997). Some thoughts on "normalization" in speech perception. Talker variability in speech processing, 6(2), 932.

[16] Prinsloo, C. P. (2000). A comparative acoustic analysis of the long vowels and diphthongs of Afrikaans and South African English. PhD thesis, University of Pretoria.

[17] Schmid, S., Lee, W. S., \& Zee, E. (2011). An acoustic analysis of palatal obstruents in two romance varieties. The Journal of the Acoustical Society of America, 96(4), 77-89.

[18] Sussman, H. M., Fruchter, D., Hilbert, J., \& Sirosh, J. (1998). Linear correlates in the speech signal: The orderly output constraint. Behavioral and Brain Sciences, 21(2), 241-259.

[19] Udoh, L.I (2003). An introduction to phonemic analysis. Lagos: Concept Publications Ltd.

[20] Umeodinka, A. U. (2016). Distinctive feature theory. In B. M. Mbah, Theories of linguistics (pp. 12-25). Nsukka: University of Nigeria Press Ltd.

[21] http://kunnampallilgejo.blogspot.com/2012/09/acoustic-theories-of-speech-production.html.

[22] http://kunnampallilgejo.blogspot.com/2012/09/acoustic-theory-of-speech-production.html.

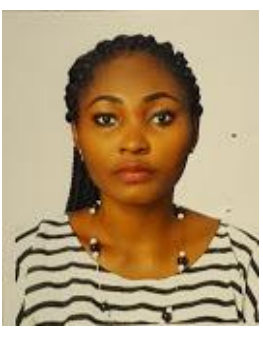

Benita Nneka Anyasi had her WAEC Certificate in 2007 from Federal Government Girls' College, Ezzamgbo, a B.A in Linguistics at Ebonyi State University in 2013 and M.A in Linguistics at the University of Nigeria, Nsukka in 2020. She has a number of scholarly publications to her credit. Among her publications is 'Semiotic analysis of political cartoons in some Nigerian national newspapers. In Mbah, B. M, Agbedo, C. U, Okeke, C. O, Okeke, G. T \& Ezebube, C. C. (eds.) Ugo gbuzuo: Study of language and literature. A festschrift in honour of Prof. G. I. Nwaozuzu. Benita N. Anyasi is also voluntarily helping children to find their footings educationally.

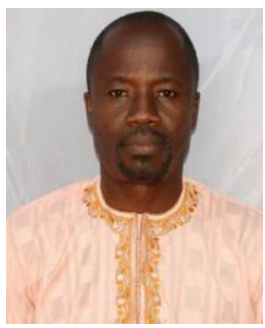

Olusanmi Olasunkanmi Babarinde was born in Gbongan Osun State on 22nd May, 1974. He had his Bachelor of Arts Degree at the University of Ilorin. He obtained M.A and PhD degrees in Linguistics at the University of Nigeria in 2006 and 2012 respectively. His area of specialization is phonology, morphology, and language documentation. He is a postdoctoral student in the Department of Linguistics and Nigerian Languages, University of Nigeria Nsukka. He has a number of scholarly publications to his credit. These include "Computer-assisted language instruction and language learning: Evidence from the English-learning Yoruba talking books 1-5. Language Matters: Studies in the Languages of Africa. 50(2), 100-111"; "Theme, diction and prosodic systems in Yoruba lullabies. International Research in Children's Literature, 12(1). 1833"; A constraint-based analysis of morphological processes in the Ibibio language. Journal of Language Teaching and Research, 11(2), 242-251.

His professional associations include Linguistic Association of Nigeria, Association for the Promotion of Yoruba Language and Culture, and Modern Language Association of Nigeria.

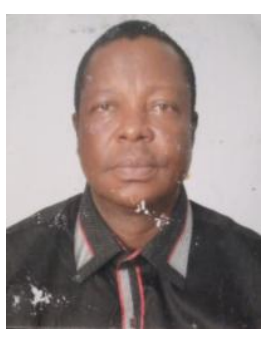

George Iloene Okedinachi is a Senior Lecturer in Linguistics at the University of Nigeria, Nsukka. I taught Linguistics and Igbo Language at Ebonyi State University Abakaliki, Nigeria from 2004 to 2015 before joining the University of Nigeria, Nsukka. My main research interests are phonetics, phonology and Igbo Language. I am also interested in the various interfaces of phonetics and phonology in the Igbo Language. I have published in reputable journals and contributed book chapters both at home and abroad. I am a Fellow of the American Council of Learned Societies and a three time attendee of the highly competitive bi-annual African Linguistics School in 2009, 2011 and 2014 that held in Ghana, Benin Republic and Nigeria. He is currently the editor of Nsukka Journal of Language and Literature (NJALL) of the University of Nigeria, Nsukka. 